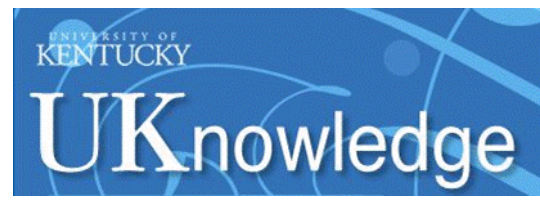

University of Kentucky

UKnowledge

Molecular Modeling and Biopharmaceutical Center Faculty Publications

3-2018

\title{
The Role of Human Dopamine Transporter in NeuroAIDS
}

Jun Zhu

University of South Carolina

Subramaniam Ananthan

Southern Research Institute

Chang-Guo Zhan

University of Kentucky, chang-guo.zhan@uky.edu

Follow this and additional works at: https://uknowledge.uky.edu/mmbc_facpub

Part of the Chemicals and Drugs Commons, and the Pharmacy and Pharmaceutical Sciences

Commons

Right click to open a feedback form in a new tab to let us know how this document benefits you.

\section{Repository Citation}

Zhu, Jun; Ananthan, Subramaniam; and Zhan, Chang-Guo, "The Role of Human Dopamine Transporter in NeuroAIDS" (2018). Molecular Modeling and Biopharmaceutical Center Faculty Publications. 18.

https://uknowledge.uky.edu/mmbc_facpub/18

This Article is brought to you for free and open access by the Molecular Modeling and Biopharmaceutical at UKnowledge. It has been accepted for inclusion in Molecular Modeling and Biopharmaceutical Center Faculty Publications by an authorized administrator of UKnowledge. For more information, please contact UKnowledge@lsv.uky.edu. 


\section{The Role of Human Dopamine Transporter in NeuroAIDS}

\section{Digital Object Identifier (DOI)}

https://doi.org/10.1016/j.pharmthera.2017.10.007

\section{Notes/Citation Information}

Published in Pharmacology \& Therapeutics, v. 183, p. 78-89.

(c) 2017 Elsevier Inc. All rights reserved.

This manuscript version is made available under the CC-BY-NC-ND 4.0 license https://creativecommons.org/licenses/by-nc-nd/4.0/.

The document available for download is the author's post-peer-review final draft of the article. 
Published in final edited form as:

Pharmacol Ther. 2018 March ; 183: 78-89. doi:10.1016/j.pharmthera.2017.10.007.

\title{
The role of human dopamine transporter in NeuroAIDS
}

\author{
Jun Zhu a ${ }^{\text {, }}$, Subramaniam Ananthan ${ }^{\mathrm{b}}$, and Chang-Guo Zhan ${ }^{\mathrm{c}, \mathrm{d}, \mathrm{e}}$ \\ aDepartment of Drug Discovery and Biomedical Sciences, College of Pharmacy, University of \\ South Carolina, Columbia, SC. USA \\ bepartment of Chemistry, Drug Discovery Division, Southern Research Institute, Birmingham, \\ $\mathrm{AL}$ \\ 'Molecular Modeling and Biopharmaceutical Center, College of Pharmacy, University of Kentucky, \\ Lexington, $\mathrm{KY}$ \\ ${ }^{d}$ Center for Pharmaceutical Research and Innovation, College of Pharmacy, University of \\ Kentucky, Lexington, KY \\ eDepartment of Pharmaceutical Sciences, College of Pharmacy, University of Kentucky, \\ Lexington, $\mathrm{KY}$
}

\section{Abstract}

HIV-associated neurocognitive disorder (HAND) remains highly prevalent in HIV infected individuals and represents a special group of neuropathological disorders, which are associated with HIV-1 viral proteins, such as transactivator of transcription (Tat) protein. Cocaine abuse increases the incidence of HAND and exacerbates its severity by enhancing viral replication. Perturbation of dopaminergic transmission has been implicated as a risk factor of HAND. The presynaptic dopamine (DA) transporter (DAT) is essential for DA homeostasis and dopaminergic modulation of the brain function including cognition. Tat and cocaine synergistically elevate synaptic DA levels by acting directly on human DAT (hDAT), ultimately leading to dysregulation of DA transmission. Through integrated computational modeling and experimental validation, key residues have been identified in hDAT that play a critical role in Tat-induced inhibition of DAT and induce transporter conformational transitions. This review presents current information regarding neurological changes in DAT-mediated dopaminergic system associated with HIV infection, DAT-mediated adaptive responses to Tat as well as allosteric modulatory effects of novel compounds on hDAT. Understanding the molecular mechanisms by which Tat induces DATmediated dysregulation of DA system is of great clinical interest for identifying new targets for an early therapeutic intervention for HAND.

\section{Keywords}

HIV-1 Tat; dopamine transporter; cocaine; allosteric modulator; mutation

*Corresponding Author: Jun Zhu, MD., PhD, Department of Drug Discovery and Biomedical Sciences, College of Pharmacy, University of South Carolina, 715 Sumter Street, Columbia, SC 29208, USA. Tel: +1-803-777-7924; Fax: +1-803-777-8356, zhuj@cop.sc.edu.

The authors declare that there are no conflicts of interest. 


\section{Introduction}

HIV infection continues to be a major global public health issue with an estimated thirty-five million people worldwide living with HIV. Despite the widespread use of efficacious antiretroviral therapies to control peripheral HIV infection and improve the life of HIV patients, more than $50 \%$ of HIV-1 positive individuals suffer from neurological complications collectively referred to as HIV-associated neurocognitive disorder (HAND) (Heaton et al., 2010). HIV can enter the brain and produce proviral DNA by viral replication in the early stage of HIV infection, which contribute to the development of HAND (Nath et al., 2011; Smith et al., 2017). Since antiretroviral medications cannot cross the blood-brain barrier while infected monocytes carrying HIV can (Burdo et al., 2013; McArthur et al., 2010; Saylor et al., 2016), HIV replication and production of viral proteins can be persistent in the brain of HIV infected patients treated with combination antiretroviral therapy (cART). Most HAND patients experience cognitive, memory, motor, and behavioral deficits (Gartner, 2000; McArthur et al., 2004; Rackstraw, 2011). The HAND patients present the neuropathological conditions and neurocognitive deficits that emerge from the continuous exposure of the CNS to HIV-1, viral proteins, immune inflammation, and cART (BrackWerner, 1999; Clifford et al., 2013; Frankel et al., 1998; Johnston et al., 2001; King et al., 2006; Power et al., 1998). Among the viral proteins, transactivator of transcription (Tat) protein plays a crucial role in the neurotoxicity and cognitive impairment evident in neuroAIDS (King et al., 2006; Rappaport et al., 1999). Importantly, drugs of abuse, such as cocaine have been shown to increase the incidence of HAND and its severity by enhancing viral replication (Ferris et al., 2008; Nath et al., 2001). Currently, there are no promising therapeutic strategies for HAND. Considering the progressive and neurodegenerative nature of HAND, establishing an early intervention strategy would be beneficial to the preservation of neurocognitive function in HIV-infected individuals.

Converging lines of clinical observations, supported by imaging (Chang et al., 2008; Wang et al., 2004), neuropsychological performance testing (Kumar et al., 2011; Meade et al., 2011), and postmortem examinations (Gelman et al., 2012), have implicated the dysregulation of dopamine (DA) system with the abnormal neurocognitive function observed in HAND (Berger et al., 2000; Purohit et al., 2011). The presynaptic DA transporter (DAT)-mediated DA reuptake is essential for normal DA homeostasis and dopaminergic modulation of the brain function including attention, learning, memory, and motivation. In vitro, the interplay of Tat and cocaine augments synaptic DA levels and Tat release by inhibiting DAT activity (Ferris et al., 2010; Zhu et al., 2009). Prolonged exposure to Tat protein eventually causes DAT-mediated dysregulation of DA to accelerate the progression of HAND (Gaskill et al., 2017; Purohit et al., 2011). Indeed, human DA transporter (hDAT) activity is strikingly reduced in HIV-1-infected cocaine-using patients, correlating with the severity of HIV-1 associated cognitive deficits (Chang et al., 2008; Wang et al., 2004). However, the molecular mechanisms underlying HIV infection-impaired DA transport process are still largely unclear. Therefore, there is a pressing need to define the molecular mechanism(s) by which the impaired DA system by HIV-1 infection affects the progression of HAND in concurrent cocaine abusers. The recently published work has demonstrated that Tat-induced inhibition of DAT is mediated by binding to allosteric binding 
site(s) on DAT, not by interacting with the DA uptake site (Yuan et al., 2015; Zhu et al., 2011; Zhu et al., 2009). Accordingly, attenuating Tat binding to DAT would be expected to have minimal influence on physiological DA transport. To achieve these goals, a greater understanding the intermolecular interactions between Tat and hDAT is needed, which involves identifying key residues in hDAT with which Tat interacts and the mechanisms by which Tat induces inhibition of DA transport. This review focuses on recent investigations regarding neurological changes in DAT-mediated dopaminergic system associated with HIV infection, DAT-mediated adaptive responses to Tat as well as allosteric modulatory effects of novel compounds on hDAT.

\section{Viral protein, dopamine system and HIV-associated neurocognitive disorder}

\subsection{HIV-1 viral proteins}

Viral replication and proviral DNA induction within the central nervous system (CNS) in the early HIV-1 infection (Nath et al., 2011) have been implicated as a risk determinant of HAND (Berger et al., 2000; Purohit et al., 2011). Since most antiretroviral therapy medications cannot cross the blood-brain barrier (Buckner et al., 2006), these medications have no influence on the production of viral proteins in the CNS. Therefore, viral proteins are associated with the persistence of HIV infection-induced neuropathology and subsequent cognitive deficits (Brack-Werner, 1999; Frankel et al., 1998; Johnston et al., 2001; Power et al., 1998). The HIV genome contains three major genes, $5^{\prime}$ gag-pol-env- $3^{\prime}$, encoding major structural proteins as well as essential enzymes (Shrivastav et al., 2008). Proteins encoded by the HIV genome are classified as 1) viral structure proteins, Gag polyprotein, Pol polyproteins, and envelop proteins, gp120 and gp41;2) essential regulatory proteins, Tat and Rev; and 3) accessory regulatory proteins, nef, vpr, vif and vpu (King, 1994). Among the viral proteins, Tat protein plays a crucial role in regulating the reverse transcription of viral genome RNA, ensuring efficient synthesis of viral mRNAs (Shrivastav et al., 2008). Tat is a nonstructural viral protein that is encoded from the first and second exons comprised of amino acids 1-72 and 73-101, respectively. Tat-induced neurotoxicity primarily contributes to HIV infection associated cognitive impairment evident in neuroAIDS (King et al., 2006; Rappaport et al., 1999). Tat is secreted from HIV infected cells (Ensoli et al., 1990) and further taken up by the surrounding microglia and neurons (Ensoli et al., 1993). Tat can be detected in DA-rich brain area (basal ganglia and related structure) (Del Valle et al., 2000; Hudson et al., 2000; Lamers et al., 2010) and in the sera (Westendorp et al., 1995; Xiao et al., 2000) of HIV-1 infected patients. However, it is still not clear what the actual biological concentration of Tat (for producing effects on DAT activity) is at or around the synapse or how this effective concentration of Tat might be reflected in cerebrospinal fluid of HIVinfected patients.

\subsection{Dysregulation of dopaminergic neurotransmission}

DA-rich brain regions (basal ganglia and related structures) are highly susceptible to the effects of both HIV infection and substance use. Long-term exposure to HIV viral proteins impairs the central dopaminergic transmission (Berger et al., 2000; Koutsilieri et al., 2002;

Pharmacol Ther. Author manuscript; available in PMC 2019 March 01. 
Nath et al., 1987) and the brain pathways controlling motivation (Berridge, 2007; Everitt et al., 2005; Wise et al., 1987). In the early stage of HIV infection, increased levels of DA and decreased DA turnover are found in the cerebrospinal fluid of therapy-naïve HIV patients in asymptomatic infection (Scheller et al., 2010), which may contribute to decreased levels of DA in DA-rich brain regions (Kumar et al., 2009; Kumar et al., 2011; Sardar et al., 1996) in the advanced stages of HIV infection. Importantly, HIV-induced elevated levels of extracellular DA in CNS can stimulate viral replication in human macrophages within DArich brain regions (Gaskill et al., 2013; Gaskill et al., 2009; Gaskill et al., 2014), resulting in viral protein release, which has been implicated in the pathophysiology of HAND (Li et al., 2009). Thus, understanding the molecular mechanism(s) of viral proteins-mediated neuropathological changes in HAND is of great scientific and clinical interest.

\subsection{HIV associated neurocognitive and behavior deficits}

HAND is a spectrum of disorders generally divided into three main groups: asymptomatic neurocognitive impairment (ANI; 33\%), mild neurocognitive disorders (MND, 20-30\%), and the more severe albeit rare HIV-associated dementia (HAD; 2-8\%) (Heaton et al., 2010; McArthur et al., 2010). Several risk factors are linked to the development of HAND, including cardiovascular risk factors, age, hepatitis $\mathrm{C}$ virus infection, and substances of abuse (Saylor et al., 2016). Among these factors, comorbidities have been considered as a key factor for cognitive impairment of HAND. In addition, early HIV infection of the CNS is believed to contribute to the development of HAND, and evidence suggests that early infected brain can subsequently serve as a sanctuary for HIV replication, thereby limiting the opportunity for a sterilizing cure or eradication (Fois et al., 2015). For example, during the first weeks of HIV infection, infected monocytes carrying HIV enter the CNS and viral proteins can be produced in macrophages by viral replication. Macrophages, the major type of infected cells in the brain, can become HIV reservoirs in the brain and promote inflammation and neuronal damage (Carvallo et al., 2017). Previous studies showed that elevated DA levels can increase HIV entry into human macrophages and HIV replication, thereby stimulating Tat release from the infected cells (Gaskill et al., 2014). It has been highlighted that cocaine and Tat protein synergistically elevate DA levels by inhibiting DAT function (Gaskill et al., 2017; Purohit et al., 2011). Although numerous studies show a variety of potential biomarkers for HAND, the majority of these are associated with HAD rather than ANI and MND, which are most common forms of cognitive impairment (Saylor et al., 2016). Thus, further understanding of the underlying molecular mechanisms and the differences in biomarkers across the spectrum of HAND will ultimately facilitate the identification and development of precision therapeutics for early stage of HAND.

\section{Identifying Tat binding sites on human dopamine transporter}

Clinically, Wang et al (2004) reported that HIV infected patients with associated dementia had significantly lower DAT availability in putamen and ventral striatum, which is the first evidence of decreased DAT associated with the pathogenesis of HIV dementia (Wang et al., 2004). Moreover, the decreased DAT in the basal ganglia was greater in HIV patients with comorbid cocaine use than HIV dementia patients (Chang et al., 2008), which is correlated with impaired learning and memory performance (Hsieh et al., 2010; Mozley et al., 2001). 
In contrast to the decreased DAT, one study on postmortem brain tissue from HAND patients (Gelman et al., 2006) reported increased levels of DAT expression in the striatum. Thus, the distinct and opposing patterns of HIV infection associated alteration of DAT expression suggest that different stages of HIV infection with or without substance use may influence DAT levels. Further studies to extensively examine the neuropathological changes in DAT expression and activity in HIV infected individuals including the all factors such as the stages of HIV infection, age, and substance use, are warranted. Nevertheless, these clinical observations suggest that developing neuroprotective agents that protect dopaminergic system from HIV infection associated DAT impairments would be beneficial to the preservation of neurocognitive function in HIV-infected individuals.

Since HIV does not infect rodents, several approaches have been used for studying the effects of viral proteins on DAT function and DAT-mediated effects through: 1) rodent brain

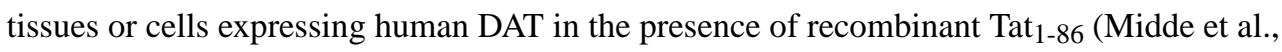
2013; Midde et al., 2015; Perry et al., 2010; Quizon et al., 2016; Wallace et al., 2006; Zhu et al., 2009); 2) intra-brain region infusion of recombinant Tat (Harrod et al., 2008; Zhu et al., 2015); 3) Doxycycline-induced Tat-transgenic (iTat) mouse model (Kim et al., 2003; Perry et al., 2010); and 4) HIV-1 transgenic rat model (Ray et al., 2003; Reid et al., 2001; Zhu et al., 2016). In vitro exposure of rat striatal synaptosomes or cells expressing hDAT to recombinant Tat $_{1-86}\left(140-500 \mathrm{nM}\right.$, final concentration) displays a decrease in $\left[{ }^{3} \mathrm{H}\right] \mathrm{DA}$ uptake in a concentration dependent manner (Midde et al., 2013; Midde et al., 2015; Quizon et al., 2016; Zhu et al., 2009). Intrastriatal bilateral injection of $15 \mu \mathrm{g} / \mu \mathrm{l}$ of recombinant Tat ${ }_{1-72}$ significantly enhances cocaine-induced total activity and alters the development of cocainemediated behavioral sensitization in rats (Harrod et al., 2008). An in vivo microdialysis study reported that intra-accumbal infusion of recombinant $\mathrm{Tat}_{1-86}(4 \mu \mathrm{g} / \mu \mathrm{l})$ significantly reduces DAT-mediated uptake/release efficiency in rats (Ferris et al., 2009). Furthermore, intra-ventral tegmental area recombinant $\operatorname{Tat}_{1-86}(10 \mu \mathrm{g} / \mu \mathrm{l})$ alters the mesocorticolimbic ERK and CREB signaling in rats (Zhu et al., 2015). These findings suggest that in vivo exposure of Tat disrupts the mesocorticolimbic pathways, which is consistent with the previous studies (Bansal et al., 2000; Zauli et al., 2000). With regard to genetically expressing viral proteins in animal models, DAT function and expression are altered in the HIV-1Tg rats (Zhu et al., 2016). Recently, McIntosh et al (2015) reported that HIV-1Tg rats exhibit a greater affinity for the binding of cocaine to DAT compared to control Fisher 344 rats (McIntosh et al., 2015). iTat mouse model utilizes a "tetracycline-on" system coupled to $\mathrm{Tat}_{1-86}$ protein coding gene that becomes transcriptionally active Tat when doxycycline is present (Kim et al., 2003; Perry et al., 2010). Although inducible expression of Tat in this model is not equivalent to human HIV-infection and does not induce the same host response, this model displays extensive neuropathological changes such as loss of cerebellum and cortex, neuronal death (apoptosis), astrocytosis, degeneration of neuronal dendrites, and the CNS infiltration of monocytes and activated T lymphocytes (Kim et al., 2003). In addition, this model exhibit a significant changes in DAT function and expression (Perry et al., 2010) and recapitulates many aspects of cognitive impairments observed in HIV infected individuals such as impairments of reversal learning, novel object recognition, and spatial learning and memory (Carey et al., 2012; Fitting et al., 2013; Paris, Singh, et al., 2014), and increased cocaine-conditioned place preference (Paris, Carey, et al., 2014). Therefore, this 
model offers specific advantages to study Tat-mediated dysregulation of DA transmission. In addition to Tat, recent studies show that other viral proteins, such as gp120 and Nef also influence DAT activity (Acharjee et al., 2014; Hu et al., 2013).

\subsection{Tat interacts with human DAT directly}

A question of significant interest is whether Tat interacts with DAT protein directly through protein-protein interaction. Studies demonstrated that Tat protein interacts biophysically and biochemically with DAT as a direct protein-protein interaction, which was validated by Surface plasmon resonance (SPR) analysis (Zhu et al., 2009), co-immunoprecipitation (CoIP) and Glutathione S-transferase (GST)-Tat (350 $\mathrm{nM}$ recombinant Tat $\left.{ }_{1-86}\right)$ pull down assays (Midde et al., 2013). These investigations greatly support the later work with mapping Tat binding sites in hDAT. Although several forms of Tat $\left(\right.$ Tat $_{1-72}$, Tat ${ }_{1-86}$ and Tat $\left.{ }_{1-101}\right)$ are available for laboratory studies, recombinant Tat ${ }_{1-86}$ has been extensively used to study its neuropathological effects on the CNS (Aksenova et al., 2006; Bruce-Keller et al., 2003; Nath et al., 1996; Zhu et al., 2009; Zhu et al., 2015). Evidence shows that Tat ${ }_{1-72}$, Tat $_{1-86}$, and full length Tat ${ }_{1-101}$ released from Tat-expressing cells exhibit equivalent inhibitory effect on DAT function (Midde et al., 2013). There are two clade B types of Tat ${ }_{1-86}$, including the

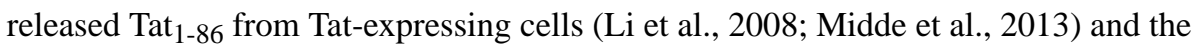
recombinant Tat ${ }_{1-86}$ (Diatheva, Fano, Italy or ImmunoDX, Woburn, MA) (Quizon et al., 2016; Sun et al., 2017). Since the recombinant Tat is considerably less potent than Tat released from Tat-expressing astrocytes (Li et al., 2008; Li et al., 2009), higher concentrations of this commonly used recombinant Tat protein may be required to adequately mimic the effects of Tat constitutively produced in the HIV-1 infected cells. However, the advantage of using the recombinant Tat is that it is a purified protein and can be used at exact molar concentrations for the designed experiments. Peptides derived from the first exon of Tat, including Tat $46-60$, Tat ${ }_{37-72}$, and Tat ${ }_{31-61}$, have been found to cause neurotoxicity (Nath et al., 1996; Philippon et al., 1994). Particularly, evidence shows that the cysteine-rich domain (residues 22-37) in the first exon of Tat is critical for the biological function of Tat (Bertrand et al., 2013; Debaisieux et al., 2012). Mutation of Tat cysteine 22 to glycine completely eliminated the inhibitory effect of wild type recombinant Tat ${ }_{1-86}$ (500-1000 nM, final concentration) on DAT function (Midde et al., 2015; Zhu et al., 2009). Thus, understanding the functional relevance of additional residues in Tat on modulation of DAT will provide useful feedback for identifying the recognition binding sites on hDAT for Tat protein.

\subsection{Computational structural models of dopamine transporter and Tat interaction}

As described above, Tat interacts directly with DAT (Midde et al., 2013; Zhu et al., 2009), which makes it feasible to perform computational modeling for studying the interaction of Tat with DAT. It is essential to understand how hDAT interacts with Tat at a molecular level, especially the detailed hDAT-Tat binding mode. However, it would be a grand challenge to determine an X-ray crystal structure of hDAT-Tat binding complex in the physiological membrane environment. In fact, X-ray crystal structure is not available even for hDAT itself. Nevertheless, state-of-the-art molecular modeling techniques have provided useful tools to model the possible hDAT-Tat interaction. Early homology modeling studies on 3D structures of hDAT were performed by using the X-ray crystal structure of $\mathrm{Na}^{+} / \mathrm{H}^{+}$antiporter or 
Lactose permease (LacY, e.g. PDB entry of $1 \mathrm{PV} 7$ with a resolution of $3.6 \AA$ ) as a template. $\mathrm{X}$-ray crystal structure of leucine transporter from Aquifex aeolicus $\left(\mathrm{LeuT}_{\mathrm{Aa}}\right)$ that became available in 2005 was considered as a more suitable template for modeling the neurotransmitter sodium symporter (NSS) family (Singh et al., 2008; Yamashita et al., 2005) of transporters to which DAT belongs. The LeuT $\mathrm{Aa}$-based first homology model of hDAT was first reported in 2007 (Huang et al., 2007). Several computational and experimental studies on the structures of hDAT and associated transporters have addressed some critical questions of the NSS members (Gedeon et al., 2010; Gelman et al., 2012; Guptaroy et al., 2009; Henry et al., 2011; Huang et al., 2009; Huang et al., 2007; Koldso et al., 2011; Shan et al., 2011; Stockner et al., 2013; Sucic et al., 2010). Although the LeuT $\mathrm{Aa}_{\text {-based 3D }}$ structures of hDAT have been proven as a valuable model in predicting the hDAT-Tat interaction (Midde et al., 2013), the LeuT $_{\mathrm{Aa}}$-based 3D structures of hDAT are not perfect due to the fact that the sequence identity between LeuT $\mathrm{Aa}_{\mathrm{Aa}}$ and $\mathrm{hDAT}$ is less than $25 \%$. The recent hDAT structural models reported in literature (Yuan et al., 2015) were obtained from homology modeling using the X-ray crystal structure (Penmatsa et al., 2013, 2015; Wang et al., 2015) of drosophila DAT (dDAT). Interestingly, the dDAT-based hDAT model (Yuan et al., 2015) in the outward-open state is essentially the same as the corresponding state of the LeuT $_{A a}$-based model, but provides additional finer details. Therefore, the dDAT-based hDAT structure may be considered as a refined 3D model of the $\mathrm{LeuT}_{\mathrm{Aa}}$-based hDAT structure (Yuan, Huang, et al., 2016). The sequence identity between hDAT and dDAT is $46 \%$, which is sufficient for constructing a satisfactory homology model (Nayeem et al., 2006; Sali et al., 1995).

Through the dDAT-modeled hDAT structures, further computational modeling studies aimed to understand how Tat protein via its recognition binding sites on hDAT interacts with hDAT (Midde et al., 2013; Midde et al., 2015; Yuan et al., 2015; Yuan, Huang, et al., 2016). This modeling reveals that the DA uptake is associated with the conformational conversion of hDAT from the outward-open state to the outward-occluded state and then to the inwardopen state (Yuan, Huang, et al., 2016). Furthermore, the computational modeling prediction indicates that Tat protein directly interacts with hDAT in the outward-open state, which is validated by experimental studies (Midde et al., 2013; Midde et al., 2015). Based on this principle, antagonizing DAT-mediated DA uptake may be achieved by either blocking the DA binding or preventing the conformational conversion of hDAT after DA binding (Yuan, Huang, et al., 2016). According to the 3D model of hDAT-Tat interaction complex, the binding of Tat with hDAT would permit the binding of in a way without competing with DA binding, but preventing the conformational conversion from the outward-open state to the other states (outward-occluded and inward-open states). Therefore, the Tat binding should not compete with the DA binding. Further, the computationally predicted hDAT-Tat binding model revealed the roles of some key residues (such as Y88, K92, Y470, and H547) of hDAT in binding with Tat, suggesting that amino-acid substitution on any of these residues will weaken the hDAT-Tat binding. Further, in a most recently reported study, computational modeling indicated that residue H547 of hDAT plays a crucial role in not only the hDAT-Tat binding, but also DA uptake by hDAT, predicting that the H547A mutation will not only considerably attenuate Tat-induced inhibition of DA uptake, but also significantly increase the $\mathrm{V}_{\max }$ of $\mathrm{hDAT}$ for DA uptake. The above computational models and predictions were 
followed by extensive experimental tests that support the models and predictions as discussed below.

\subsection{Pharmacological validation of the key residues on dopamine transporter for Tat binding}

To obtain experimental evidence for the mode of binding predicted by the 3D structural model of hDAT binding with Tat, the effects of Tat on DA reuptake by hDAT bearing mutations of the identified key residues have been validated and refined by site-directed mutagenesis and pharmacological assays (Yuan et al., 2015; Yuan, Huang, et al., 2016). This work was recently highlighted in the HIV research by Nature Chemical Biology (Bucci, 2015). Through the integrated computational modeling prediction and experimental validation, key residues can be identified in hDAT with which Tat interacts, which are critical for Tat-induced inhibition of DAT. In general, in vitro exposure of cell lines expressing hDAT to $140 \mathrm{nM}$ Tat $_{1-86}$ displayed a $30 \%$ decrease in $\left[{ }^{3} \mathrm{H}\right] \mathrm{DA}$ uptake in WT hDAT (Midde et al., 2013; Midde et al., 2015; Quizon et al., 2016). One may expect that mutations of identified binding residues on hDAT for Tat would attenuate the Tat-induced inhibition of DA transport. One caveat is that Tat-induced inhibition of hDAT in cell system may not reflect hDAT-Tat interaction in HIV infected human brain and does not measure the biological effects on HIV-1 Tat protein on hDAT function. However, through this in vitro model we can explore the molecular mechanism(s) of Tat inhibition on the DA uptake by DAT and interactions with cocaine.

\subsubsection{The functional influences of $\mathrm{Y} 88, \mathrm{~K} 92$ and $\mathrm{Y} 470$ of hDAT on DA transport process-The amino acid sequence of hDAT has 12 transmembrane (TM) helices.} According to the computationally modeled hDAT structures (Midde et al., 2015; Yuan et al., 2015), TM1, TM6 and TM10 are crucial for conformational conversion of DA transport process from the outward-open to the outward-occluded state of hDAT. This is consistent with the previous studies showing R85-D476 (between TM1 and TM10) salt bridge as a key indication for the conformational conversion (Gedeon et al., 2010; Huang et al., 2007;

Manepalli et al., 2012; Schmitt et al., 2011). Therefore, any structural changes involving the intermolecular interactions of TM1, TM6 and/or TM10 are expected to influence the conformational conversion, thereby altering DA uptake by hDAT. Interestingly, computational modeling using the dDAT-based hDAT model predicts Tat binds most favorably with the outward-open state of hDAT. Further analysis of the molecular dynamics simulations of the hDAT-Tat binding structure revealed that Y88, K92, and Y470 of hDAT are key residues involved in the intermolecular interaction between hDAT and Tat (Yuan et al., 2015). Among these residues, K92 (TM1b) interacts with D313 (TM6a) side chains forming a favorable salt bridge during the molecular dynamics simulations on the hDAT-DA binding structures, which is necessary for the conformational conversion of hDAT during the DA uptake process. As a result, elimination of the K92-D313 salt bridge is expected to impair/slow down the DA uptake process. This computational prediction has been validated by site-directed mutagenesis and in vitro pharmacological assays. For example, mutations of K92 (K92M) (Midde et al., 2015) and D313 (D313N) (Chen et al., 2004) decrease the $\mathrm{V}_{\max }$ for DA uptake by $70 \%$ and $80 \%$, respectively, relative to wild type hDAT. In addition, Y470 residue (in TM10) of hDAT is a key component of a hydrophobic region, which is critical 
for stabilizing the compact structure of hDAT. As a result, significant change in the hydrophobic property or shape of Y470 by mutations (Y470H or Y470A but not Y470F) could decrease the $\mathrm{V}_{\max }$ for DA uptake (Midde et al., 2013; Midde et al., 2015). The aromatic ring of the Y88 side chain is sandwiched between TM1b and extracellular loop 4 (EL4) in a hydrophobic region as a stable intermolecular structure of hDAT. As a result, mutation of $\mathrm{Y} 88$ (Y88F) retains the reuptake function of hDAT without change in the $\mathrm{V}_{\max }$ (Midde et al., 2015).

\subsubsection{The functional influences of H547 of hDAT on DA transport process-In}

addition to R85-D476 salt bridge, computational modeling prediction has revealed that a stable structural motif (Y548-Y470-Y551, denoted as YYY motif) is also an essential structural feature for the conformational conversion of hDAT during DA transport process (Yuan, Quizon, et al., 2016). This YYY motif contains a typical U-turn loop with a hydrophobic region which is associated with extracellular loop 6 (EL6) and TM10a. Any amino-acid-based structural changes that destabilize the YYY motif would impair the formation of the R85-D476 salt bridge, which then influences the conformational conversion associated with the DA transport process. As described above, mutation of $\mathrm{Y} 470(\mathrm{Y} 470 \mathrm{H})$ that destabilizes the YYY motif by disrupting the hydrophobic interaction dramatically decreases the $V_{\max }$ for DA uptake (Midde et al., 2013; Midde et al., 2015). Interestingly, mutations of $\mathrm{H} 547$ residue that is adjacent to Y548 of the YYY motif is also expected to significantly affect the stability of the YYY motif (Yuan, Quizon, et al., 2016). The H547A mutant improves the strength of the R85-D476 salt bridge that is comparable to that in wild type hDAT, whereas the salt bridge is broken in the H547P and H547D, thus, affecting the DA transport by hDAT (Yuan, Quizon, et al., 2016). The computational modeling predictions were validated pharmacologically. For example, the $\mathrm{V}_{\max }$ for DA uptake is increased by $196 \%$ in H547A and decreased by $99 \%$ in H547P and 60\% in H547D, respectively, but not altered in H547R (Quizon et al., 2016).

\subsubsection{Attenuation of Tat-induced inhibition of DA transport-Through the} computational modeling and molecular dynamics simulations, it is possible to identify the most favorable hDAT-Tat binding mode, including a cation- $\pi$ interaction involving Y470 of hDAT and two hydrogen-bonding interactions involving hDAT residues Y88 and K92 (Yuan et al., 2015). Based on this prediction, the cation- $\pi$ interaction between hDAT and Tat would be eliminated by $\mathrm{Y} 470 \mathrm{H}$ and Y470A mutations but not Y470F. Mutations of K92 (K92M) and $\mathrm{Y} 88$ (Y88F) are expected to inhibit the Tat binding with minimal influence by the mutated Y88. Accordingly, in vitro pharmacological studies reveal that exposure to $140 \mathrm{nM}$ Tat $_{1-86}$ induces a 30\% reduction of the specific DA uptake in wild type hDAT, which is completely attenuated in mutants Y470H, Y470A, and Y88F, but not in Y470F mutant (Midde et al., 2013; Midde et al., 2015). In addition, both the side chain and backbone of H547 residue on hDAT forms a hydrogen bond with residue R49 of HIV-Tat (Yuan, Quizon, et al., 2016), which is expected to be broken with the H547 mutation. As a result, Tat ${ }_{1-86}$ $(140 \mathrm{nM})$-induced inhibition of the specific $\left[{ }^{3} \mathrm{H}\right] \mathrm{DA}$ uptake in wild type hDAT is attenuated in H547 mutants (H547A, H547P, and H547D) and associated hDAT residue Y551H . 
Based on the modeled Tat-hDAT binding structure, a total of 20 residues of hDAT were predicted to be key residues for the hDAT-Tat interaction (Yuan et al., 2015). Table 1 shows a summary of the partial results of the different effects of mutants on basal DA uptake and Tat-induced inhibition of DA transport, which can be categorized as: 1) retaining normal DA uptake but attenuating Tat's inhibitory effect (Y88F and H547R) or 2) not affecting Tat's inhibitory effect (Y470F); 3) reducing DA uptake and attenuating Tat's effect (Y470H, Y470A, K92M, H547P, and H547D); and 4) enhancing normal DA uptake while attenuating Tat's effect (H547A). Thus, understanding the binding residues on hDAT for Tat will provide a mechanistic basis for identifying targets for developing compounds that specifically block Tat binding site(s) in DAT or diminish the Tat binding affinity by allosteric modulation.

\section{Allosteric modulatory effect of Tat protein on DA transport}

An estimated prevalence of comorbid HIV infection and drug abuse is about $40-70 \%$ of HIV positive individuals. Drugs of abuse, such as cocaine, have been shown to increase the incidence of HAND and exacerbate the severity of HAND by enhancing viral replication while there is no FDA-approved therapy for cocaine addiction. Cocaine is thought to mediate most of its behavioral and rewarding effects via blockade of the DAT and the resulting elevation in extracellular brain DA levels (Dutta et al., 2003). Interplay of Tat and cocaine augments synaptic DA levels and Tat release by inhibiting DAT activity (Ferris et al., 2010; Zhu et al., 2009), which may contribute to the progression of HAND underlying the cognitive deficits in HIV-1 positive cocaine-using individuals (Chang et al., 2008; Wang et al., 2004). Therefore, there is a pressing need to define the molecular mechanism(s) by which how Tat through their recognition binding sites on hDAT potentiates cocaine-induced inhibition on DAT function, thereby leading to dysfunction of the DA system. Attenuating inhibitory effects of Tat and cocaine on DA transport are important for preventing the DATmediated dysfunction of DA system in HIV infected patients with cocaine abuse.

\subsection{Cocaine and Tat protein differentially interact with hDAT}

Molecular model for DAT binding of cocaine constructed from the high-resolution structure of the bacterial transporter homolog LeuT suggests that the binding site for cocaine is deeply buried between transmembrane segments 1, 3,6 and 8, and overlaps with the binding sites for the substrate, DA (Beuming et al., 2008). This cocaine-DAT model is validated by detailed mutagenesis and by trapping the radiolabeled cocaine analog $\left[{ }^{3} \mathrm{H}\right] \mathrm{CFT}$ in the transporter, which demonstrates the molecular basis for the competitive inhibition of DA transport by cocaine. Moreover, according to further molecular modeling and dynamics simulations, the cocaine competes with DA for binding with DAT (Huang et al., 2009). Taken together, these studies conclude that it is impossible to generate a competitive inhibitor of cocaine binding that treats cocaine addiction without itself inhibiting DA uptake. In contrast, with respect to Tat protein, Tat-induced inhibition of DAT is mediated by binding to allosteric binding site(s) on DAT, not by interacting with the DA uptake site (Yuan et al., 2015; Zhu et al., 2011; Zhu et al., 2009). This conclusion is supported by the following pharmacological studies: 1) recombinant $\mathrm{Tat}_{1-86}(140 \mathrm{nM}$, final concentration) decreased the $\mathrm{V}_{\max }$ of $\left[{ }^{3} \mathrm{H}\right] \mathrm{DA}$ uptake and $\mathrm{B}_{\max }$ of $\left[{ }^{3} \mathrm{H}\right]$ WIN 35,428 binding and increased 
the apparent $\mathrm{K}_{\mathrm{m}}$ and $\mathrm{K}_{\mathrm{d}}$ values in a concentration-dependent manner (Zhu et al., 2009); 2) recombinant Tat ${ }_{1-86}$ displays a similar decrease in $\mathrm{IC}_{50}$ values for cocaine-induced inhibition of $\left[{ }^{3} \mathrm{H}\right] \mathrm{DA}$ uptake by a competitive inhibitor such as indatraline as well as by allosteric modulators such as the SRI compounds (Pariser et al., 2008; Zhu et al., 2011); and 3) the addition of recombinant $\operatorname{Tat}_{1-86}(5 \mu \mathrm{M})$ after cocaine significantly slowed the dissociation rate of $\left[{ }^{3} \mathrm{H}\right]$ WIN 35,428 (Zhu et al., 2011). The observed results demonstrate that Tat modulates the transporter conformation transitions by binding to allosteric binding site(s), not by interacting with the DA uptake site where cocaine and WIN35,428 bind. Consistent with these results, computational modeling revealed that Tat-DAT interaction does not overlap with the substrate DA binding site (Yu et al., 2013).

\subsection{Allosteric modulation of DAT by cocaine and Tat}

In general, transporter ligands that interact with neurotransmitter transport are typically classified into two categories: cocaine-like competitive inhibitors and amphetamine-like substrates (Schmitt et al., 2013), which increase extracellular monoamine levels and display addiction liability similar to that of cocaine. In addition to competitive inhibitors and substrates of transporter, there is a growing interest in allosteric modulators of DAT. Allosteric sites on hDAT may represent novel drug targets that display neutral cooperativity with the classical DA uptake site. If inhibition of DA uptake by cocaine or Tat is the result of an allosteric mechanism, it would be possible, at least in theory, to generate an allosteric modulator that might attenuate cocaine and Tat binding to DAT without affecting DA transport for treatment of individuals with comorbid HIV infection and cocaine use. DATmediated DA transport is a dynamic DA translocation process, which is regulated by three typical conformational states: Outward-open $\rightarrow$ Outward-occluded $\rightarrow$ Inward-open (Beuming et al., 2008; Kniazeff et al., 2008; Zhao et al., 2010). The substrate (DA) transport process is associated with the transporter protein conformational changes. Conformational transitions via substrate- and ligand-binding sites on DAT are responsible for allosteric modulation of DAT (Shan et al., 2011). Cocaine and Tat protein preferentially stabilize the DAT in the outward-open state, resulting in reduction of DA uptake by directly blocking DA uptake site (Loland et al., 2002; Reith et al., 2001; Yuan et al., 2015; Yuan, Huang, et al., 2016). Generally, the processes of the conformational changes in DA transport involve conversions between outward-open and inward-open states (Zhao et al., 2010). In support of an allosteric modulation for cocaine binding, previous studies have reported that mutations of several residues in DAT produce differential effects on cocaine and DA binding (Chen et al., 2005; Chen et al., 2006; Lin et al., 2002; Loland et al., 2004; Uhl et al., 2003). However, the marked decrease in affinity for cocaine by mutating these residues is the result of an altered conformational equilibrium of DAT toward an inward-open conformation, rather than because of disruption of a direct interaction between the identified residues and cocaine (Loland et al., 2004; Loland et al., 2002; Sen et al., 2005). Given that Tat protein and cocaine synergistically impair DAT function, a detailed understanding of the interplay between Tat and cocaine in disrupting DAT-mediated DA dysregulation may provide therapeutic insights into HAND in concurrent cocaine abusers. As described above, several key residues have been identified in hDAT, which are critical for Tat-induced inhibition of DAT and transporter conformational changes. Interestingly, compared to WT hDAT, mutations in these residues lead to an increase in affinity for cocaine (Midde et al., 2013; 
Midde et al., 2015; Quizon et al., 2016), which may implicate a high rate of cocaine use in HIV-infected individuals. Computational modeling of Tat-DAT suggested that mutating these residues for Tat binding may modulate the conformation of cocaine binding with hDAT via an allosteric modulatory mechanism. Occupancy of the endogenous $\mathrm{Zn}^{2+}$ binding site in WT hDAT (His193, His375, and Glu396) stabilizes the transporter in an outwardopen state, which allows DA to bind but inhibits its translocation, thereby increasing [ ${ }^{3}$ H]WIN35,428 binding sites (Moritz et al., 2013; Norregaard et al., 1998), but decreasing DA uptake (Loland et al., 2003). On the basis of this principle, it was found that mutating Tat binding residues alters $\mathrm{Zn}^{2+}$ modulation of $\left[{ }^{3} \mathrm{H}\right] \mathrm{DA}$ uptake and $\left[{ }^{3} \mathrm{H}\right] \mathrm{WIN} 35,428$ binding sites as well as the basal DA/or MPP ${ }^{+}$efflux (Midde et al., 2013; Midde et al., 2015; Quizon et al., 2016). By using a hDAT homology model to dock Tat into the transporter and MD simulations to probe the conformational state of hDAT bound to Tat, it was found that Tat can only bind to the outward-open structure with favorable binding energies (Yuan et al., 2015). Therefore, it was predicted that Tat binding would block the entry pathway of the DA substrate, thereby inhibiting DA clearance from the presynaptic cleft. These findings suggest that Tat protein via its recognition residues in hDAT produces inhibition of DA transport by altering transporter conformational transitions.

\subsection{Developing biological probes for attenuating Tat binding to DAT}

Evidence showing Tat-induced allosteric modulation of DA transport provides a molecular basis for developing allosteric modulatory molecules that decrease the affinity and maximal binding potential of cocaine and Tat. This could be a viable approach for treatment of cocaine- and Tat-induced dysfunction of DA system. Identifying suitable molecular probes and performing proof of concept studies is of great scientific and clinical interest. Recent studies have reported that a novel quinazoline series (SRI-compounds) of monoamine transporter ligands, function as partial antagonists of DA uptake without the full inhibitory profile that is typical of classic competitors of DAT (Pariser et al., 2008; Rothman et al., 2015; Rothman et al., 2009; Schmitt et al., 2013). There are number of advantages in using allosteric modulators of DAT as preferred therapeutic agents over classic competitor of the DA uptake site. Such allosteric modulators could potentially attenuate the effect of cocaine and Tat on DAT while having minimal effects on the physiological DA transmission. Although it is still unclear how the SRI-compounds through their interaction with allosteric modulatory sites on hDAT alter the affinity and maximal binding potential of cocaine and Tat, recent studies have demonstrated that the SRI-compounds attenuate the inhibitory effects of cocaine and Tat on DA uptake and binding (Sun et al., 2017; Zhu et al., 2011). For example, compared to indatraline, a competitive inhibitor for DAT, SRI-compounds produce $\sim 40 \%$ reduction of the specific $\left[{ }^{3} \mathrm{H}\right] \mathrm{DA}$ uptake and display $\sim 30 \%$ increase in $\mathrm{IC}_{50}$ values for inhibiting $\left[{ }^{3} \mathrm{H}\right] \mathrm{DA}$ uptake by cocaine in rat synaptosomes and cells expressing hDAT (Sun et al., 2017; Zhu et al., 2011). These findings suggest that SRI-compounds display a partial antagonism on DA transport in an allosteric modulation manner. Furthermore, SRIcompounds were evaluated in a dissociation assay, in which the dissociation is initiated by blocking the forward reaction with $10 \mu \mathrm{M}$ cocaine, a concentration high enough to occupy all DAT binding sites followed by assessing the cocaine-mediated dissociation rate of $\left[{ }^{3} \mathrm{H}\right]$ WIN 35,428 in the presence of SRI-compounds. In this assay, cocaine as a competitive inhibitor of DAT potently dissociates the binding of the cocaine analog $\left[{ }^{3} \mathrm{H}\right]$ WIN 35,428 , 
and the addition of SRI-compounds after cocaine slows the dissociation rate of $\left[{ }^{3} \mathrm{H}\right]$ WIN 35,428 . These findings further demonstrate that SRI-compounds modulate the conformation of DAT by binding to a site to which cocaine or WIN 35,428 does not bind, thereby leading to alteration of the kinetics of the $\left[{ }^{3} \mathrm{H}\right] \mathrm{DA}$ uptake and $\left[{ }^{3} \mathrm{H}\right]$ WIN 35,428 binding.

As described above for Tat-mediated allosteric modulation, one recent study reported that SRI-30827 attenuated $40 \mathrm{nM}$ recombinant Tat $1-86$-induced inhibition of $\left[{ }^{3} \mathrm{H}\right]$ WIN35,428 binding, indicating that Tat binding to DAT can be modulated by allosteric ligands (Sun et al., 2017). Computational docking study shows that SRI-30827 interacts with hDAT extracellular loop 6 that contacts directly with Tat and can partially inhibit DAT uptake function (Sun et al., 2017). Since the conformational changes in DA transport process involve conversions between the outward- and inward-open conformations (Zhao et al., 2010), further docking studies were performed using homology models of hDAT at the different conformational states and two SRI-compounds. These studies revealed that the SRI-compounds could only fit into the outward-open hDAT model. Interestingly, the docked pose of the ligands at hDAT-Tat complex reveal that compounds such as SRI-30827 could potentially influence the conformation of residues Tyr470 and Tyr88 in the EL6 region, and thus likely modulate the binding of Tat on hDAT via an allosteric modulatory mechanism. However, it is still unclear whether the attenuation of Tat-induced inhibition of $\left[{ }^{3} \mathrm{H}\right]$ WIN35,428 binding by SRI-30827 is through direct interaction with Tat binding site or other allosteric binding sites. Recent studies have demonstrated that DAT tyrosine 470 and 88 replaced by histidine $(\mathrm{Y} 470 \mathrm{H})$ or phenylalanine $(\mathrm{Y} 88 \mathrm{~F})$ retain the normal surface DAT expression and attenuate Tat-induced inhibition of DA transport (Midde et al., 2013; Midde et al., 2015). Further, mutating these two residues prevented zinc-induced regulation of DA uptake and WIN35,438 binding (Midde et al., 2013; Midde et al., 2015), which may suggest that these two residues are critical for Tat allosteric modulation of DAT. According to the previous modeling results, in the outward-open hDAT conformation, Y470 extends to the extracellular region where it interacts directly with Tat residues (Yuan et al., 2015). In the SRI-compound docked models, SRI compounds may potentially influence the conformation of residues Tyr470 and Tyr88 with EL6 region, and thus likely modulate the binding of Tat on hDAT via an allosteric modulatory mechanism. Hence, although SRI-compounds may not interact directly with either Tyr470 or Tyr88 for competing with Tat binding, they can weaken the Tat DAT binding by changing the DAT conformation allosterically. One possibility is that $\mathrm{Y} 470 \mathrm{H}$ - and $\mathrm{Y} 88 \mathrm{~F}-$-mediated transporter conformational transitions may contribute to these changes in cocaine-mediated inhibition of DA uptake and dissociation in these mutants. Taken together, considering both Y470 and Y88 are associated with hDATTat interactions, developing compounds directly targeting the specific binding sites on hDAT for Tat could provide a viable approach for treatment of Tat-induced dopamine dysfunction. Alternatively, developing DAT-based allosteric modulator interacting with the specific residues that are structurally distinct from Tat binding sites would be another possible therapeutic approach.

\section{Reversible Tat-induced dysfunction of dopamine transporter}

Given Tat-induces dysregulation of DA system by inhibiting DA transport, it is critical to define whether the inhibitory effects of Tat on DAT function is reversible, since the 
dysfunction occurs long before dopaminergic neuron loss and the development of HIVassociated dementia (Wang et al., 2004). As such, effective prevention of the early effects of Tat exposure in the brain of HIV-infected individuals is a potentially promising approach to prevent Tat-mediated neurocognitive impairments. This will provide insight into understanding the most appropriate therapeutic window during early HIV infection.

\subsection{Tat regulates DAT trafficking}

The efficacy of DA uptake largely depends on DAT expression in the plasma membrane, which is dynamically modulated by a trafficking mechanism (Zhu et al., 2008). Particularly, dynamic cell surface localization of DAT is regulated by cellular signaling pathways and endocytotic trafficking (Melikian, 2004). It has been demonstrated that Tat inhibits DA uptake in a time- and concentration-dependent manner (Zhu et al., 2009), Particularly, a 15min exposure of rat synaptosomes to $1 \mu \mathrm{M}$ recombinant Tat ${ }_{1-86}$ induced a rapid and reversible decrease in the $\mathrm{V}_{\max }$ of $\left[{ }^{3} \mathrm{H}\right] \mathrm{DA}$ uptake without changes in total DAT levels (Zhu et al., 2009), suggesting that Tat-induced reduction of DA uptake is not caused by DAT protein degradation. Further, the transporter turnover rate, which reflects the number of DA molecules transported per second per site, was determined and shown that 15-min exposure of synaptosomes to $1 \mu \mathrm{M}$ recombinant Tat ${ }_{1-86}$ did not alter the ratio of $\mathrm{V}_{\max }$ for $\left[{ }^{3} \mathrm{H}\right] \mathrm{DA}$ uptake/ $\mathrm{B}_{\max }$ for $\left[{ }^{3} \mathrm{H}\right]$ WIN 35,428 binding (Zhu et al., 2009), providing evidence that a short time exposure to Tat does not decrease the DAT turnover rates. Furthermore, after 15-min exposure of rat striatal synaptosomes to $1 \mu \mathrm{M}$ recombinant $\mathrm{Tat}_{1-86}$, DAT expression was decreased by $46 \%$ in plasma membrane and increased by $49 \%$ in intracellular compartment without changes in total DAT levels (Midde et al., 2012). These data indicate that exposure to Tat results in a redistribution of DAT from the cell surface to intracellular compartments (i.e. internalization) and that loss of DAT from the plasma membrane is responsible for the decrease in $\mathrm{V}_{\max }$ observed after Tat exposure. In contrast, Perry et al (2010) reported that exposure of rat mesencephalic neurons or PC12-hDAT cells to $120 \mathrm{nM}$ recombinant Tat ${ }_{1-86}$ induces a slight decrease in DAT-mediated DA uptake at 15 min, however, the DA uptake was significantly increased by 4 -fold at $30 \mathrm{~min}$ and 2 -fold after $24 \mathrm{~h}$, respectively (Perry et al., 2010). Interestingly, using total internal reflection fluorescence assay Perry et al identified that DAT expression in plasma membrane is increased after 30-min exposure of PC12 hDAT culture to $120 \mathrm{nM}$ recombinant Tat ${ }_{1-86}$, whereas $24-\mathrm{h}$ Tat exposure increases DAT protein synthesis, suggesting that Tat in vitro influences DAT function and expression through different mechanisms (Perry et al., 2010).

The elevated DAT levels were observed in the postmortem brain tissue from HAND patients (Gelman et al., 2006). It is important to correlate the in vitro findings with in vivo evidence of dopaminergic dysfunction in the context of HAND. Perry et al reported that striatal DAT expression levels are increased in iTat mice compared to wild type control mice after 7-day administration of doxycycline, suggesting that in vivo Tat exposure alters DAT levels. However, this study did not examine the DAT levels in these animals in the absence of Tat induction, such as saline control groups (Perry et al., 2010). Moreover, it has been reported that the HIV-1 Tg rats exhibit significantly enhanced $\mathrm{V}_{\max }$ values of $\left[{ }^{3} \mathrm{H}\right] \mathrm{DA}$ uptake into rat synaptosomes of both prefrontal cortex and striatum (Zhu et al., 2016), which is opposite to the findings showing decreased DAT reuptake in vitro (Zhu et al., 2009). The increased $V_{\max }$ 
in the prefrontal cortex and striatum was accompanied by distinctly different alterations in DAT expression in the plasma membrane in a brain region-specific manner (Zhu et al., 2016). Particularly, decreased $B_{\max }$ values of $\left[{ }^{3} \mathrm{H}\right]$ WIN 35,428 binding was observed in the striatal plasma membrane fraction, indicating an increase in uptake turnover rate in HIV-1 $\mathrm{Tg}$ rats. Thus, these findings suggest that neuroadaptive changes in DAT function are evidenced in animal models with genetically expressing HIV viral proteins, perhaps in compensation for viral protein-induced abnormal dopaminergic transmission. Thus, these in vitro studies suggest that Tat-induced inhibition of DAT-mediated DA uptake is reversible, which provides insight into understanding the most appropriate therapeutic window during early HIV infection.

\subsection{Tat regulates DAT function by affecting subcellular signaling}

The dynamic regulation of DAT function is under the control of complex processes involving subcellular signaling, protein-protein interaction, substrate pretreatment, and interaction with presynaptic receptors (Zhu et al., 2008). For example, activation of protein kinase $\mathrm{C}(\mathrm{PKC})$ results in reduced DA transport activity, decreased transporter recycling and DAT cell surface expression, thereby causing reduced DA uptake (Daniels et al., 1999; Foster et al., 2016; Zahniser et al., 2004). One study reported that $0.7 \mu \mathrm{M}$ recombinant Tat $_{1-86}$-induced decrease in the specific $\left[{ }^{3} \mathrm{H}\right] \mathrm{DA}$ uptake in rat striatal synaptosomes was completely attenuated by a PKC inhibitor, BIM-1 (Midde et al., 2012). Similarly, preincubation of the synaptosomes with BIM-I completely blocked amphetamine-induced decrease $(31 \%)$ in $\left[{ }^{3} \mathrm{H}\right] \mathrm{DA}$ uptake, which is consistent with a previous report (Richards et al., 2009). Therefore, compared to amphetamine, Tat produces a similar regulatory effect on DAT uptake function through a PKC-dependent mechanism. Moreover, as described above, His547 in hDAT is a key residue for Tat binding (Quizon et al., 2016). In addition, it was found that promoting PKC phosphorylation of DAT with PMA, a PKC activator, results in $40 \%$ and $60 \%$ reduction of DA uptake in WT hDAT and H547A, respectively. Similarly, preventing PKC phosphorylation of DAT with BIM produces a 98\% and $42 \%$ increase in DA uptake in WT hDAT and H547A, respectively. This suggests a differential sensitivity to PMA- or BIM-induced activation or inhibition of DAT function between WT hDAT and H547A. One possibility is that mutation of His547 alters basal levels of PKC-mediated phosphorylation of DAT, thereby resulting in the enhanced DA uptake. Recent studies demonstrate that the serine-7 residue in DAT is critical for PKC-dependent DAT phosphorylation (Moritz et al., 2013), and the alanine mutation of serine-7 results in an increase in DA uptake relative to WT DAT (Moritz et al., 2015). As the PKC phosphorylation sites on cytoplasmic domain (intracellular side) of hDAT are structurally far away from the residue H547 on the extracellular side of hDAT (Midde et al., 2013; Yuan, Quizon, et al., 2016), the H547A mutation is likely to regulate the PKC-mediated phosphorylation by allosteric effect. In addition to PKC signaling, evidence shows that inhibition of GSK-3 $\beta$ stabilizes $\beta$-catenin and increases the number of DA neurons from ventral mesencephalon precursor (Castelo-Branco et al., 2004). Perry et al (2010) reported that $120 \mathrm{nM}$ recombinant $\mathrm{Tat}_{1-86}$ significantly elevates plasma membrane-localized DAT expression and DA transport by activation of glycogen synthase kinase-3 (GSK-3) signaling pathway (Perry et al., 2010). GSK-3 $\beta$ inhibition prevented Tat-induced increases in membrane DAT and membrane calpain activity, highlighting mechanisms by which GSK-3 $\beta$ 
inhibitors may confer neuroprotective benefits for dopaminergic symptoms in HAND (Ances et al., 2008; Dewhurst et al., 2007).

Collectively, these observations may suggest the potential regulatory pathways for DAT compensatory response to in vitro Tat exposure by 1) enhancing reuptake capacity, 2) increasing DAT turnover rate, 3) trafficking DAT to the plasma membrane, and 4) changing subcellular signaling pathways. Although there is limited evidence supporting the conclusion, these studies provide novel insights for future investigations of Tat-induced dysregulation of dopaminergic transmission by DAT. Long lasting exposure to viral proteins and elevated DA eventually lead to dysregulation of DAT-mediated DA transmission that potentiates HAND severity and accelerates its progression.

\section{Conclusion}

There are two outstanding reviews that discuss recent investigations regarding the interactions between the Tat protein and dopaminergic neurotransmission (Gaskill et al., 2017; Purohit et al., 2011). What has emerged from the extensive studies is a clear link between perturbation of dopaminergic transmission by exposure of the CNS to Tat and the risk of HAND. Given the importance of DAT in DA homeostasis and synaptic DA transmission, this review highlights the impact of DAT on the Tat-induced dysregulation of DA system. Most importantly, Tat and cocaine synergistically elevate synaptic DA levels by acting directly on hDAT, which ultimately leads to dysregulation of dopamine transmission. This process provides a mechanistic explanation for why cocaine abuse increases the incidence of HAND and exacerbates its severity. Fig. 1 provides a summary cartoon of what has been described in this review of recent investigations, which highlights a vicious circle of HIV-1 infection-induced impairment of dopaminergic neurotransmission. There appears to be multiple mechanisms by which DAT can compensate for Tat-induced dysregulation of DA system, which maintain a constant level of DA at the synaptic cleft. In the past few years, much progress has been made in identifying the intermolecular interactions of Tat and hDAT and their impact on DAT-mediated DA neurotransmission. Allosteric modulators may have therapeutic utility in HAND, not only by preventing Tat binding to hDAT but also by reversing DAT function. However, fundamental questions remain as to the biological form of Tat protein, its concentration in the CNS, and how Tat influences DAT-mediated DA system in the early stage of HIV infection. Through integrated computational modeling and experimental approaches, the unique residues on hDAT are identified and validated; however, these binding residues for Tat may not reflect the hDAT-Tat binding mode in the brains of HIV infected patients. To explore the role of the identified residues in HIV infection-induced neurocognitive deficits in inducible Tat transgenic mice is an essential task in future studies. Notably, the prefrontal cortex is a critical brain region for higher cognitive function (Dalley et al., 2004; Miller et al., 2001; Ridderinkhof et al., 2004), where norepinephrine (NE) transporter (NET) is more concentrated than the DAT and plays a primary role in reuptake of DA (Moll et al., 2000; Moron et al., 2002). The serotonin transporter has a low affinity to effectively take up and transport DA at physiological levels, whereas the NET can transport DA and NE (Horn, 1973; Raiteri et al., 1977). For these reasons, it is likely that Tat-induced dysfunction of DA system could be mediated by inhibition of both DAT and NET, which is evidenced by increased prevalence of comorbid 
psychiatric conditions related to NE and serotonin dysregulation in HIV infected patients (Adams et al., 2016; Jallow et al., 2017; Miners et al., 2014; Mirani et al., 2015).

Determining the mechanistic basis underlying the Tat interactions with DAT/NET is currently underway because it may reveal novel therapeutic possibilities for preventing the increase in comorbid conditions as well as HAND. Overall, further understanding of the molecular mechanism(s) of Tat-induced impairment of DA transport process will greatly provide a novel mechanistic basis for developing compounds that specifically attenuate cocaine and Tat binding site(s) in hDAT to normalize DA transmission to physiological levels in HIV-infected cocaine-using patients. In summary, the findings presented herein raise the exciting possibility of potential therapeutic intervention for HIV infected patients with concurrent cocaine abuse. Proof of this concept could emerge from efforts directed toward discovery and development of candidate in vivo probe molecules with the desired allosteric modulation profiles coupled with favorable drug-like attributes. The effectiveness of an early intervention for HAND to preserve neurocognitive functions in HIV-infected individuals may ultimately depend on a treatment approach that combines compound(s) that specifically attenuate Tat binding site(s) in DAT with antiretroviral therapy, without affecting the normal function of DAT.

\section{Acknowledgments}

This research was supported by grants from the National Institute on Drug Abuse to Jun Zhu (R01DA035714 and R21DA041932). The synthesis of the compounds was supported by a grant from the National Institute on Drug Abuse to Subramaniam Ananthan (R33 DA029962).

\section{References}

Acharjee S, Branton WG, Vivithanaporn P, Maingat F, Paul AM, Dickie P, Baker GB, Power C. HIV-1 Nef expression in microglia disrupts dopaminergic and immune functions with associated manialike behaviors. Brain Behav Immun. 2014; 40:74-84. [PubMed: 24607605]

Adams C, Zacharia S, Masters L, Coffey C, Catalan P. Mental health problems in people living with HIV: changes in the last two decades: the London experience 1990-2014. AIDS Care. 2016; 28(Suppl 1):56-59. [PubMed: 26888472]

Aksenova MV, Silvers JM, Aksenov MY, Nath A, Ray PD, Mactutus CF, Booze RM. HIV-1 Tat neurotoxicity in primary cultures of rat midbrain fetal neurons: changes in dopamine transporter binding and immunoreactivity. Neurosci Lett. 2006; 395:235-239. [PubMed: 16356633]

Ances BM, Letendre SL, Alexander T, Ellis RJ. Role of psychiatric medications as adjunct therapy in the treatment of HIV associated neurocognitive disorders. Int Rev Psychiatry. 2008; 20:89-93. [PubMed: 18240065]

Bansal AK, Mactutus CF, Nath A, Maragos W, Hauser KF, Booze RM. Neurotoxicity of HIV-1 proteins gp120 and Tat in the rat striatum. Brain Res. 2000; 879:42-49. [PubMed: 11011004]

Berger JR, Arendt G. HIV dementia: the role of the basal ganglia and dopaminergic systems. J Psychopharmacol. 2000; 14:214-221. [PubMed: 11106299]

Berridge KC. The debate over dopamine's role in reward: the case for incentive salience. Psychopharmacology (Berl). 2007; 191:391-431. [PubMed: 17072591]

Bertrand SJ, Aksenova MV, Mactutus CF, Booze RM. HIV-1 Tat protein variants: critical role for the cysteine region in synaptodendritic injury. Exp Neurol. 2013; 248:228-235. [PubMed: 23811015]

Beuming T, Kniazeff J, Bergmann ML, Shi L, Gracia L, Raniszewska K, Newman AH, Javitch JA, Weinstein H, Gether U, Loland CJ. The binding sites for cocaine and dopamine in the dopamine transporter overlap. Nat Neurosci. 2008; 11:780-789. [PubMed: 18568020]

Brack-Werner R. Astrocytes: HIV cellular reservoirs and important participants in neuropathogenesis. AIDS. 1999; 13:1-22. [PubMed: 10207540] 
Bruce-Keller AJ, Chauhan A, Dimayuga FO, Gee J, Keller JN, Nath A. Synaptic transport of human immunodeficiency virus-Tat protein causes neurotoxicity and gliosis in rat brain. J Neurosci. 2003; 23:8417-8422. [PubMed: 12968004]

Bucci M. Viral mechanisms: Tat modulates DAT. Nat Chem Biol. 2015; 11:240. [PubMed: 25785419]

Buckner CM, Luers AJ, Calderon TM, Eugenin EA, Berman JW. Neuroimmunity and the blood-brain barrier: molecular regulation of leukocyte transmigration and viral entry into the nervous system with a focus on neuroAIDS. J Neuroimmune Pharmacol. 2006; 1:160-181. [PubMed: 18040782]

Burdo TH, Lackner A, Williams KC. Monocyte/macrophages and their role in HIV neuropathogenesis. Immunol Rev. 2013; 254:102-113. [PubMed: 23772617]

Carey AN, Sypek EI, Singh HD, Kaufman MJ, McLaughlin JP. Expression of HIV-Tat protein is associated with learning and memory deficits in the mouse. Behav Brain Res. 2012; 229:48-56. [PubMed: 22197678]

Carvallo L, Lopez L, Fajardo JE, Jaureguiberry-Bravo M, Fiser A, Berman JW. HIV-Tat regulates macrophage gene expression in the context of neuroAIDS. PLoS One. 2017; 12:e0179882. [PubMed: 28640909]

Castelo-Branco G, Rawal N, Arenas E. GSK-3beta inhibition/beta-catenin stabilization in ventral midbrain precursors increases differentiation into dopamine neurons. J Cell Sci. 2004; 117:57315737. [PubMed: 15522889]

Chang L, Wang GJ, Volkow ND, Ernst T, Telang F, Logan J, Fowler JS. Decreased brain dopamine transporters are related to cognitive deficits in HIV patients with or without cocaine abuse. Neuroimage. 2008; 42:869-878. [PubMed: 18579413]

Chen N, Zhen J, Reith ME. Mutation of Trp84 and Asp313 of the dopamine transporter reveals similar mode of binding interaction for GBR12909 and benztropine as opposed to cocaine. J Neurochem. 2004; 89:853-864. [PubMed: 15140185]

Chen R, Han DD, Gu HH. A triple mutation in the second transmembrane domain of mouse dopamine transporter markedly decreases sensitivity to cocaine and methylphenidate. J Neurochem. 2005; 94:352-359. [PubMed: 15998286]

Chen R, Tilley MR, Wei H, Zhou F, Zhou FM, Ching S, Quan N, Stephens RL, Hill ER, Nottoli T, Han $\mathrm{DD}, \mathrm{Gu} \mathrm{HH}$. Abolished cocaine reward in mice with a cocaine-insensitive dopamine transporter. Proc Natl Acad Sci U S A. 2006; 103:9333-9338. [PubMed: 16754872]

Clifford DB, Ances BM. HIV-associated neurocognitive disorder. Lancet Infect Dis. 2013; 13:976986. [PubMed: 24156898]

Dalley JW, Cardinal RN, Robbins TW. Prefrontal executive and cognitive functions in rodents: neural and neurochemical substrates. Neurosci Biobehav Rev. 2004; 28:771-784. [PubMed: 15555683]

Daniels GM, Amara SG. Regulated trafficking of the human dopamine transporter. Clathrin-mediated internalization and lysosomal degradation in response to phorbol esters. J Biol Chem. 1999; 274:35794-35801. [PubMed: 10585462]

Debaisieux S, Rayne F, Yezid H, Beaumelle B. The ins and outs of HIV-1 Tat. Traffic. 2012; 13:355363. [PubMed: 21951552]

Del Valle L, Croul S, Morgello S, Amini S, Rappaport J, Khalili K. Detection of HIV-1 Tat and JCV capsid protein, VP1, in AIDS brain with progressive multifocal leukoencephalopathy. J Neurovirol. 2000; 6:221-228. [PubMed: 10878711]

Dewhurst S, Maggirwar SB, Schifitto G, Gendelman HE, Gelbard HA. Glycogen synthase kinase 3 beta (GSK-3 beta) as a therapeutic target in neuroAIDS. J Neuroimmune Pharmacol. 2007; 2:9396. [PubMed: 18040831]

Dutta AK, Zhang S, Kolhatkar R, Reith ME. Dopamine transporter as target for drug development of cocaine dependence medications. Eur J Pharmacol. 2003; 479:93-106. [PubMed: 14612141]

Ensoli B, Barillari G, Salahuddin SZ, Gallo RC, Wong-Staal F. Tat protein of HIV-1 stimulates growth of cells derived from Kaposi's sarcoma lesions of AIDS patients. Nature. 1990; 345:84-86. [PubMed: 2184372]

Ensoli B, Buonaguro L, Barillari G, Fiorelli V, Gendelman R, Morgan RA, Wingfield P, Gallo RC. Release, uptake, and effects of extracellular human immunodeficiency virus type 1 Tat protein on cell growth and viral transactivation. J Virol. 1993; 67:277-287. [PubMed: 8416373] 
Everitt BJ, Robbins TW. Neural systems of reinforcement for drug addiction: from actions to habits to compulsion. Nat Neurosci. 2005; 8:1481-1489. [PubMed: 16251991]

Ferris MJ, Frederick-Duus D, Fadel J, Mactutus CF, Booze RM. The human immunodeficiency virus-1-associated protein, Tat1-86, impairs dopamine transporters and interacts with cocaine to reduce nerve terminal function: a no-net-flux microdialysis study. Neuroscience. 2009; 159:12921299. [PubMed: 19344635]

Ferris MJ, Frederick-Duus D, Fadel J, Mactutus CF, Booze RM. Hyperdopaminergic tone in HIV-1 protein treated rats and cocaine sensitization. J Neurochem. 2010; 115:885-896. [PubMed: 20796175]

Ferris MJ, Mactutus CF, Booze RM. Neurotoxic profiles of HIV, psychostimulant drugs of abuse, and their concerted effect on the brain: current status of dopamine system vulnerability in NeuroAIDS. Neurosci Biobehav Rev. 2008; 32:883-909. [PubMed: 18430470]

Fitting S, Ignatowska-Jankowska BM, Bull C, Skoff RP, Lichtman AH, Wise LE, Fox MA, Su J, Medina AE, Krahe TE, Knapp PE, Guido W, Hauser KF. Synaptic dysfunction in the hippocampus accompanies learning and memory deficits in human immunodeficiency virus type-1 Tat transgenic mice. Biol Psychiatry. 2013; 73:443-453. [PubMed: 23218253]

Fois AF, Brew BJ. The Potential of the CNS as a Reservoir for HIV-1 Infection: Implications for HIV Eradication. Curr HIV/AIDS Rep. 2015; 12:299-303. [PubMed: 25869939]

Foster JD, Vaughan RA. Phosphorylation mechanisms in dopamine transporter regulation. J Chem Neuroanat. 2016

Frankel AD, Young JA. HIV-1: fifteen proteins and an RNA. Annu Rev Biochem. 1998; 67:1-25. [PubMed: 9759480]

Gartner S. HIV infection and dementia. Science. 2000; 287:602-604. [PubMed: 10691542]

Gaskill PJ, Calderon TM, Coley JS, Berman JW. Drug induced increases in CNS dopamine alter monocyte, macrophage and T cell functions: implications for HAND. J Neuroimmune Pharmacol. 2013; 8:621-642. [PubMed: 23456305]

Gaskill PJ, Calderon TM, Luers AJ, Eugenin EA, Javitch JA, Berman JW. Human immunodeficiency virus (HIV) infection of human macrophages is increased by dopamine: a bridge between HIVassociated neurologic disorders and drug abuse. Am J Pathol. 2009; 175:1148-1159. [PubMed: 19661443]

Gaskill PJ, Miller DR, Gamble-George J, Yano H, Khoshbouei H. HIV, Tat and dopamine transmission. Neurobiol Dis. 2017; 105:51-73. [PubMed: 28457951]

Gaskill PJ, Yano HH, Kalpana GV, Javitch JA, Berman JW. Dopamine receptor activation increases HIV entry into primary human macrophages. PLoS One. 2014; 9:e108232. [PubMed: 25268786]

Gedeon PC, Indarte M, Surratt CK, Madura JD. Molecular dynamics of leucine and dopamine transporter proteins in a model cell membrane lipid bilayer. Proteins. 2010; 78:797-811. [PubMed: 19899168]

Gelman BB, Lisinicchia JG, Chen T, Johnson KM, Jennings K, Freeman DH Jr, Soukup VM. Prefrontal Dopaminergic and Enkephalinergic Synaptic Accommodation in HIV-associated Neurocognitive Disorders and Encephalitis. J Neuroimmune Pharmacol. 2012; 7:686-700. [PubMed: 22391864]

Gelman BB, Spencer JA, Holzer CE 3rd, Soukup VM. Abnormal striatal dopaminergic synapses in National NeuroAIDS Tissue Consortium subjects with HIV encephalitis. J Neuroimmune Pharmacol. 2006; 1:410-420. [PubMed: 18040813]

Guptaroy B, Zhang M, Bowton E, Binda F, Shi L, Weinstein H, Galli A, Javitch JA, Neubig RR, Gnegy ME. A juxtamembrane mutation in the $\mathrm{N}$ terminus of the dopamine transporter induces preference for an inward-facing conformation. Mol Pharmacol. 2009; 75:514-524. [PubMed: 19098122]

Harrod SB, Mactutus CF, Fitting S, Hasselrot U, Booze RM. Intra-accumbal Tat1-72 alters acute and sensitized responses to cocaine. Pharmacol Biochem Behav. 2008; 90:723-729. [PubMed: 18582493]

Heaton RK, Clifford DB, Franklin DR Jr, Woods SP, Ake C, Vaida F, Ellis RJ, Letendre SL, Marcotte TD, Atkinson JH, Rivera-Mindt M, Vigil OR, Taylor MJ, Collier AC, Marra CM, Gelman BB, McArthur JC, Morgello S, Simpson DM, McCutchan JA, Abramson I, Gamst A, Fennema- 
Notestine C, Jernigan TL, Wong J, Grant I, Group, C. HIV-associated neurocognitive disorders persist in the era of potent antiretroviral therapy: CHARTER Study. Neurology. 2010; 75:20872096. [PubMed: 21135382]

Henry LK, Iwamoto H, Field JR, Kaufmann K, Dawson ES, Jacobs MT, Adams C, Felts B, Zdravkovic I, Armstrong V, Combs S, Solis E, Rudnick G, Noskov SY, DeFelice LJ, Meiler J, Blakely RD. A conserved asparagine residue in transmembrane segment 1 (TM1) of serotonin transporter dictates chloride-coupled neurotransmitter transport. J Biol Chem. 2011; 286:3082330836. [PubMed: 21730057]

Horn AS. Structure-activity relations for the inhibition of catecholamine uptake into synaptosomes from noradrenaline and dopaminergic neurones in rat brain homogenates. Br J Pharmacol. 1973; 47:332-338. [PubMed: 4722047]

Hsieh PC, Yeh TL, Lee IH, Huang HC, Chen PS, Yang YK, Chiu NT, Lu RB, Liao MH. Correlation between errors on the Wisconsin Card Sorting Test and the availability of striatal dopamine transporters in healthy volunteers. J Psychiatry Neurosci. 2010; 35:90-94. [PubMed: 20184806]

$\mathrm{Hu}$ S, Sheng WS, Rock RB. CB2 receptor agonists protect human dopaminergic neurons against damage from HIV-1 gp120. PLoS One. 2013; 8:e77577. [PubMed: 24147028]

Huang X, Gu HH, Zhan CG. Mechanism for cocaine blocking the transport of dopamine: insights from molecular modeling and dynamics simulations. J Phys Chem B. 2009; 113:15057-15066. [PubMed: 19831380]

Huang X, Zhan CG. How dopamine transporter interacts with dopamine: insights from molecular modeling and simulation. Biophys J. 2007; 93:3627-3639. [PubMed: 17704152]

Hudson L, Liu J, Nath A, Jones M, Raghavan R, Narayan O, Male D, Everall I. Detection of the human immunodeficiency virus regulatory protein tat in CNS tissues. J Neurovirol. 2000; 6:145155. [PubMed: 10822328]

Jallow A, Ljunggren G, Wandell P, Wahlstrom L, Carlsson AC. HIV-infection and psychiatric illnesses - A double edged sword that threatens the vision of a contained epidemic: The Greater Stockholm HIV Cohort Study. J Infect. 2017; 74:22-28. [PubMed: 27717780]

Johnston JB, Zhang K, Silva C, Shalinsky DR, Conant K, Ni W, Corbett D, Yong VW, Power C. HIV-1 Tat neurotoxicity is prevented by matrix metalloproteinase inhibitors. Ann Neurol. 2001; 49:230241. [PubMed: 11220743]

Kim BO, Liu Y, Ruan Y, Xu ZC, Schantz L, He JJ. Neuropathologies in transgenic mice expressing human immunodeficiency virus type 1 Tat protein under the regulation of the astrocyte-specific glial fibrillary acidic protein promoter and doxycycline. Am J Pathol. 2003; 162:1693-1707. [PubMed: 12707054]

King JE, Eugenin EA, Buckner CM, Berman JW. HIV tat and neurotoxicity. Microbes Infect. 2006; 8:1347-1357. [PubMed: 16697675]

King SR. HIV: virology and mechanisms of disease. Ann Emerg Med. 1994; 24:443-449.

Kniazeff J, Shi L, Loland CJ, Javitch JA, Weinstein H, Gether U. An intracellular interaction network regulates conformational transitions in the dopamine transporter. J Biol Chem. 2008; 283:1769117701. [PubMed: 18426798]

Koldso H, Noer P, Grouleff J, Autzen HE, Sinning S, Schiott B. Unbiased simulations reveal the inward-facing conformation of the human serotonin transporter and $\mathrm{Na}(+)$ ion release. PLoS Comput Biol. 2011; 7:e1002246. [PubMed: 22046120]

Koutsilieri E, Sopper S, Scheller C, ter Meulen V, Riederer P. Involvement of dopamine in the progression of AIDS Dementia Complex. J Neural Transm. 2002; 109:399-410. [PubMed: 11956960]

Krishnamurthy H, Gouaux E. X-ray structures of LeuT in substrate-free outward-open and apo inwardopen states. Nature. 2012; 481:469-474. [PubMed: 22230955]

Kumar AM, Fernandez JB, Singer EJ, Commins D, Waldrop-Valverde D, Ownby RL, Kumar M. Human immunodeficiency virus type 1 in the central nervous system leads to decreased dopamine in different regions of postmortem human brains. J Neurovirol. 2009; 15:257-274. [PubMed: 19499455] 
Kumar AM, Ownby RL, Waldrop-Valverde D, Fernandez B, Kumar M. Human immunodeficiency virus infection in the CNS and decreased dopamine availability: relationship with neuropsychological performance. J Neurovirol. 2011; 17:26-40. [PubMed: 21165787]

Lamers SL, Salemi M, Galligan DC, Morris A, Gray R, Fogel G, Zhao L, McGrath MS. Human immunodeficiency virus-1 evolutionary patterns associated with pathogenic processes in the brain. J Neurovirol. 2010; 16:230-241. [PubMed: 20367240]

Li W, Huang Y, Reid R, Steiner J, Malpica-Llanos T, Darden TA, Shankar SK, Mahadevan A, Satishchandra P, Nath A. NMDA receptor activation by HIV-Tat protein is clade dependent. J Neurosci. 2008; 28:12190-12198. [PubMed: 19020013]

Li W, Li G, Steiner J, Nath A. Role of Tat protein in HIV neuropathogenesis. Neurotox Res. 2009; 16:205-220. [PubMed: 19526283]

Lin Z, Uhl GR. Dopamine transporter mutants with cocaine resistance and normal dopamine uptake provide targets for cocaine antagonism. Mol Pharmacol. 2002; 61:885-891. [PubMed: 11901228]

Loland CJ, Granas C, Javitch JA, Gether U. Identification of intracellular residues in the dopamine transporter critical for regulation of transporter conformation and cocaine binding. J Biol Chem. 2004; 279:3228-3238. [PubMed: 14597628]

Loland CJ, Norgaard-Nielsen K, Gether U. Probing dopamine transporter structure and function by Zn2+-site engineering. Eur J Pharmacol. 2003; 479:187-197. [PubMed: 14612149]

Loland CJ, Norregaard L, Litman T, Gether U. Generation of an activating Zn(2+) switch in the dopamine transporter: mutation of an intracellular tyrosine constitutively alters the conformational equilibrium of the transport cycle. Proc Natl Acad Sci U S A. 2002; 99:1683-1688. [PubMed: 11818545]

Manepalli S, Surratt CK, Madura JD, Nolan TL. Monoamine transporter structure, function, dynamics, and drug discovery: a computational perspective. AAPS J. 2012; 14:820-831. [PubMed: 22918625]

Masson J, Sagne C, Hamon M, El Mestikawy S. Neurotransmitter transporters in the central nervous system. Pharmacol Rev. 1999; 51:439-464. [PubMed: 10471414]

McArthur JC, McDermott MP, McClernon D, St Hillaire C, Conant K, Marder K, Schifitto G, Selnes OA, Sacktor N, Stern Y, Albert SM, Kieburtz K, deMarcaida JA, Cohen B, Epstein LG. Attenuated central nervous system infection in advanced HIV/AIDS with combination antiretroviral therapy. Arch Neurol. 2004; 61:1687-1696. [PubMed: 15534180]

McArthur JC, Steiner J, Sacktor N, Nath A. Human immunodeficiency virus-associated neurocognitive disorders: Mind the gap. Ann Neurol. 2010; 67:699-714. [PubMed: 20517932]

McIntosh S, Sexton T, Pattison LP, Childers SR, Hemby SE. Increased Sensitivity to Cocaine SelfAdministration in HIV-1 Transgenic Rats is Associated with Changes in Striatal Dopamine Transporter Binding. J Neuroimmune Pharmacol. 2015; 10:493-505. [PubMed: 25749646]

Meade CS, Lowen SB, MacLean RR, Key MD, Lukas SE. fMRI brain activation during a delay discounting task in HIV-positive adults with and without cocaine dependence. Psychiatry Res. 2011; 192:167-175. [PubMed: 21546221]

Melikian HE. Neurotransmitter transporter trafficking: endocytosis, recycling, and regulation. Pharmacol Ther. 2004; 104:17-27. [PubMed: 15500906]

Midde NM, Gomez AM, Zhu J. HIV-1 Tat Protein Decreases Dopamine Transporter Cell Surface Expression and Vesicular Monoamine Transporter-2 Function in Rat Striatal Synaptosomes. J Neuroimmune Pharmacol. 2012; 7:629-639. [PubMed: 22570010]

Midde NM, Huang X, Gomez AM, Booze RM, Zhan CG, Zhu J. Mutation of tyrosine 470 of human dopamine transporter is critical for HIV-1 Tat-induced inhibition of dopamine transport and transporter conformational transitions. J Neuroimmune Pharmacol. 2013; 8:975-987. [PubMed: 23645138]

Midde NM, Yuan Y, Quizon PM, Sun WL, Huang X, Zhan CG, Zhu J. Mutations at tyrosine 88, lysine 92 and tyrosine 470 of human dopamine transporter result in an attenuation of HIV-1 Tat-induced inhibition of dopamine transport. J Neuroimmune Pharmacol. 2015; 10:122-135. [PubMed: 25604666]

Miller EK, Cohen JD. An integrative theory of prefrontal cortex function. Annu Rev Neurosci. 2001; 24:167-202. [PubMed: 11283309] 
Miners A, Phillips A, Kreif N, Rodger A, Speakman A, Fisher M, Anderson J, Collins S, Hart G, Sherr L, Lampe FC, Study A. Health-related quality-of-life of people with HIV in the era of combination antiretroviral treatment: a cross-sectional comparison with the general population. Lancet HIV. 2014; 1:e32-40. [PubMed: 26423814]

Mirani G, Williams PL, Chernoff M, Abzug MJ, Levin MJ, Seage GR 3rd, Oleske JM, Purswani MU, Hazra R, Traite S, Zimmer B, Van Dyke RB, Team I.P.S. Changing Trends in Complications and Mortality Rates Among US Youth and Young Adults With HIV Infection in the Era of Combination Antiretroviral Therapy. Clin Infect Dis. 2015; 61:1850-1861. [PubMed: 26270680]

Moll GH, Mehnert C, Wicker M, Bock N, Rothenberger A, Ruther E, Huether G. Age-associated changes in the densities of presynaptic monoamine transporters in different regions of the rat brain from early juvenile life to late adulthood. Brain Res Dev Brain Res. 2000; 119:251-257. [PubMed: 10675775]

Moritz AE, Foster JD, Gorentla BK, Mazei-Robison MS, Yang JW, Sitte HH, Blakely RD, Vaughan RA. Phosphorylation of dopamine transporter serine 7 modulates cocaine analog binding. J Biol Chem. 2013; 288:20-32. [PubMed: 23161550]

Moritz AE, Rastedt DE, Stanislowski DJ, Shetty M, Smith MA, Vaughan RA, Foster JD. Reciprocal Phosphorylation and Palmitoylation Control Dopamine Transporter Kinetics. J Biol Chem. 2015; 290:29095-29105. [PubMed: 26424792]

Moron JA, Brockington A, Wise RA, Rocha BA, Hope BT. Dopamine uptake through the norepinephrine transporter in brain regions with low levels of the dopamine transporter: evidence from knock-out mouse lines. J Neurosci. 2002; 22:389-395. [PubMed: 11784783]

Mozley LH, Gur RC, Mozley PD, Gur RE. Striatal dopamine transporters and cognitive functioning in healthy men and women. Am J Psychiatry. 2001; 158:1492-1499. [PubMed: 11532737]

Nath A, Clements JE. Eradication of HIV from the brain: reasons for pause. AIDS. 2011; 25:577-580. [PubMed: 21160414]

Nath A, Jankovic J, Pettigrew LC. Movement disorders and AIDS. Neurology. 1987; 37:37-41. [PubMed: 3796836]

Nath A, Maragos WF, Avison MJ, Schmitt FA, Berger JR. Acceleration of HIV dementia with methamphetamine and cocaine. J Neurovirol. 2001; 7:66-71. [PubMed: 11519485]

Nath A, Psooy K, Martin C, Knudsen B, Magnuson DS, Haughey N, Geiger JD. Identification of a human immunodeficiency virus type 1 Tat epitope that is neuroexcitatory and neurotoxic. J Virol. 1996; 70:1475-1480. [PubMed: 8627665]

Nayeem A, Sitkoff D, Krystek S Jr. A comparative study of available software for high-accuracy homology modeling: from sequence alignments to structural models. Protein Sci. 2006; 15:808824. [PubMed: 16600967]

Norregaard L, Frederiksen D, Nielsen EO, Gether U. Delineation of an endogenous zinc-binding site in the human dopamine transporter. EMBO J. 1998; 17:4266-4273. [PubMed: 9687495]

Paris JJ, Carey AN, Shay CF, Gomes SM, He JJ, McLaughlin JP. Effects of conditional central expression of HIV-1 tat protein to potentiate cocaine-mediated psychostimulation and reward among male mice. Neuropsychopharmacology. 2014; 39:380-388. [PubMed: 23945478]

Paris JJ, Singh HD, Ganno ML, Jackson P, McLaughlin JP. Anxiety-like behavior of mice produced by conditional central expression of the HIV-1 regulatory protein, Tat. Psychopharmacology (Berl). 2014; 231:2349-2360. [PubMed: 24352568]

Pariser JJ, Partilla JS, Dersch CM, Ananthan S, Rothman RB. Studies of the biogenic amine transporters. 12. Identification of novel partial inhibitors of amphetamine-induced dopamine release. J Pharmacol Exp Ther. 2008; 326:286-295. [PubMed: 18441249]

Penmatsa A, Wang KH, Gouaux E. X-ray structure of dopamine transporter elucidates antidepressant mechanism. Nature. 2013; 503:85-90. [PubMed: 24037379]

Penmatsa A, Wang KH, Gouaux E. X-ray structures of Drosophila dopamine transporter in complex with nisoxetine and reboxetine. Nat Struct Mol Biol. 2015; 22:506-508. [PubMed: 25961798]

Perry SW, Barbieri J, Tong N, Polesskaya O, Pudasaini S, Stout A, Lu R, Kiebala M, Maggirwar SB, Gelbard HA. Human immunodeficiency virus-1 Tat activates calpain proteases via the ryanodine receptor to enhance surface dopamine transporter levels and increase transporter-specific uptake and Vmax. J Neurosci. 2010; 30:14153-14164. [PubMed: 20962236] 
Philippon V, Vellutini C, Gambarelli D, Harkiss G, Arbuthnott G, Metzger D, Roubin R, Filippi P. The basic domain of the lentiviral Tat protein is responsible for damages in mouse brain: involvement of cytokines. Virology. 1994; 205:519-529. [PubMed: 7526541]

Power C, McArthur JC, Nath A, Wehrly K, Mayne M, Nishio J, Langelier T, Johnson RT, Chesebro B. Neuronal death induced by brain-derived human immunodeficiency virus type 1 envelope genes differs between demented and nondemented AIDS patients. J Virol. 1998; 72:9045-9053. [PubMed: 9765449]

Purohit V, Rapaka R, Shurtleff D. Drugs of abuse, dopamine, and HIV-associated neurocognitive disorders/HIV-associated dementia. Mol Neurobiol. 2011; 44:102-110. [PubMed: 21717292]

Quizon PM, Sun WL, Yuan Y, Midde NM, Zhan CG, Zhu J. Molecular mechanism: the human dopamine transporter histidine 547 regulates basal and HIV-1 Tat protein-inhibited dopamine transport. Sci Rep. 2016; 6:39048. [PubMed: 27966610]

Rackstraw S. HIV-related neurocognitive impairment-a review. Psychol Health Med. 2011; 16:548563. [PubMed: 21745034]

Raiteri M, Del Carmine R, Bertollini A, Levi G. Effect of sympathomimetic amines on the synaptosomal transport of noradrenaline, dopamine and 5-hydroxytryptamine. Eur J Pharmacol. 1977; 41:133-143. [PubMed: 832672]

Rappaport J, Joseph J, Croul S, Alexander G, Del Valle L, Amini S, Khalili K. Molecular pathway involved in HIV-1-induced CNS pathology: role of viral regulatory protein, Tat. J Leukoc Biol. 1999; 65:458-465. [PubMed: 10204574]

Ray PE, Liu XH, Robinson LR, Reid W, Xu L, Owens JW, Jones OD, Denaro F, Davis HG, Bryant JL. A novel HIV-1 transgenic rat model of childhood HIV-1-associated nephropathy. Kidney Int. 2003; 63:2242-2253. [PubMed: 12753314]

Reid W, Sadowska M, Denaro F, Rao S, Foulke J Jr, Hayes N, Jones O, Doodnauth D, Davis H, Sill A, O’Driscoll P, Huso D, Fouts T, Lewis G, Hill M, Kamin-Lewis R, Wei C, Ray P, Gallo RC, Reitz M, Bryant J. An HIV-1 transgenic rat that develops HIV-related pathology and immunologic dysfunction. Proc Natl Acad Sci U S A. 2001; 98:9271-9276. [PubMed: 11481487]

Reith ME, Berfield JL, Wang LC, Ferrer JV, Javitch JA. The uptake inhibitors cocaine and benztropine differentially alter the conformation of the human dopamine transporter. J Biol Chem. 2001; 276:29012-29018. [PubMed: 11395483]

Richards TL, Zahniser NR. Rapid substrate-induced down-regulation in function and surface localization of dopamine transporters: rat dorsal striatum versus nucleus accumbens. $\mathbf{J}$ Neurochem. 2009; 108:1575-1584. [PubMed: 19183252]

Ridderinkhof KR, van den Wildenberg WP, Segalowitz SJ, Carter CS. Neurocognitive mechanisms of cognitive control: the role of prefrontal cortex in action selection, response inhibition, performance monitoring, and reward-based learning. Brain Cogn. 2004; 56:129-140. [PubMed: 15518930]

Rothman RB, Ananthan S, Partilla JS, Saini SK, Moukha-Chafiq O, Pathak V, Baumann MH. Studies of the biogenic amine transporters 15. Identification of novel allosteric dopamine transporter ligands with nanomolar potency. J Pharmacol Exp Ther. 2015; 353:529-538. [PubMed: 25788711]

Rothman RB, Dersch CM, Ananthan S, Partilla JS. Studies of the biogenic amine transporters. 13. Identification of "agonist" and "antagonist" allosteric modulators of amphetamine-induced dopamine release. J Pharmacol Exp Ther. 2009; 329:718-728. [PubMed: 19244097]

Sali A, Potterton L, Yuan F, van Vlijmen H, Karplus M. Evaluation of comparative protein modeling by MODELLER. Proteins. 1995; 23:318-326. [PubMed: 8710825]

Sardar AM, Czudek C, Reynolds GP. Dopamine deficits in the brain: the neurochemical basis of parkinsonian symptoms in AIDS. Neuroreport. 1996; 7:910-912. [PubMed: 8724671]

Saylor D, Dickens AM, Sacktor N, Haughey N, Slusher B, Pletnikov M, Mankowski JL, Brown A, Volsky DJ, McArthur JC. HIV-associated neurocognitive disorder - pathogenesis and prospects for treatment. Nat Rev Neurol. 2016; 12:309. [PubMed: 27080521]

Scheller C, Arendt G, Nolting T, Antke C, Sopper S, Maschke M, Obermann M, Angerer A, Husstedt IW, Meisner F, Neuen-Jacob E, Muller HW, Carey P, Ter Meulen V, Riederer P, Koutsilieri E. Increased dopaminergic neurotransmission in therapy-naive asymptomatic HIV patients is not 
associated with adaptive changes at the dopaminergic synapses. J Neural Transm. 2010; 117:699-705. [PubMed: 20454983]

Schmitt KC, Reith ME. The atypical stimulant and nootropic modafinil interacts with the dopamine transporter in a different manner than classical cocaine-like inhibitors. PLoS One. 2011; 6:e25790. [PubMed: 22043293]

Schmitt KC, Rothman RB, Reith ME. Nonclassical pharmacology of the dopamine transporter: atypical inhibitors, allosteric modulators, and partial substrates. J Pharmacol Exp Ther. 2013; 346:2-10. [PubMed: 23568856]

Sen N, Shi L, Beuming T, Weinstein H, Javitch JA. A pincer-like configuration of TM2 in the human dopamine transporter is responsible for indirect effects on cocaine binding. Neuropharmacology. 2005; 49:780-790. [PubMed: 16216288]

Shan J, Javitch JA, Shi L, Weinstein H. The substrate-driven transition to an inward-facing conformation in the functional mechanism of the dopamine transporter. PLoS One. 2011; 6:e16350. [PubMed: 21298009]

Shrivastav S, Kino T, Cunningham T, Ichijo T, Schubert U, Heinklein P, Chrousos GP, Kopp JB. Human immunodeficiency virus (HIV)-1 viral protein R suppresses transcriptional activity of peroxisome proliferator-activated receptor $\{$ gamma $\}$ and inhibits adipocyte differentiation: implications for HIV-associated lipodystrophy. Mol Endocrinol. 2008; 22:234-247. [PubMed: 17932108]

Singh SK, Piscitelli CL, Yamashita A, Gouaux E. A competitive inhibitor traps LeuT in an open-to-out conformation. Science. 2008; 322:1655-1661. [PubMed: 19074341]

Smith TJ, Auwaerter P, Knowlton A, Saylor D, McArthur J. Treatment of human immunodeficiency virus-related peripheral neuropathy with Scrambler Therapy: a case report. Int J STD AIDS. 2017; 28:202-204. [PubMed: 27330020]

Stockner T, Montgomery TR, Kudlacek O, Weissensteiner R, Ecker GF, Freissmuth M, Sitte HH. Mutational analysis of the high-affinity zinc binding site validates a refined human dopamine transporter homology model. PLoS Comput Biol. 2013; 9:e1002909. [PubMed: 23436987]

Sucic S, Dallinger S, Zdrazil B, Weissensteiner R, Jorgensen TN, Holy M, Kudlacek O, Seidel S, Cha JH, Gether U, Newman AH, Ecker GF, Freissmuth M, Sitte HH. The N terminus of monoamine transporters is a lever required for the action of amphetamines. J Biol Chem. 2010; 285:1092410938. [PubMed: 20118234]

Sun WL, Quizon PM, Yuan Y, Zhang W, Ananthan S, Zhan CG, Zhu J. Allosteric modulatory effects of SRI-20041 and SRI-30827 on cocaine and HIV-1 Tat protein binding to human dopamine transporter. Sci Rep. 2017; 7:3694. [PubMed: 28623359]

Uhl GR, Lin Z. The top 20 dopamine transporter mutants: structure-function relationships and cocaine actions. Eur J Pharmacol. 2003; 479:71-82. [PubMed: 14612139]

Wallace DR, Dodson S, Nath A, Booze RM. Estrogen attenuates gp120- and tat1-72-induced oxidative stress and prevents loss of dopamine transporter function. Synapse. 2006; 59:51-60. [PubMed: 16237680]

Wang GJ, Chang L, Volkow ND, Telang F, Logan J, Ernst T, Fowler JS. Decreased brain dopaminergic transporters in HIV-associated dementia patients. Brain. 2004; 127:2452-2458. [PubMed: 15319273]

Wang KH, Penmatsa A, Gouaux E. Neurotransmitter and psychostimulant recognition by the dopamine transporter. Nature. 2015; 521:322-327. [PubMed: 25970245]

Westendorp MO, Frank R, Ochsenbauer C, Stricker K, Dhein J, Walczak H, Debatin KM, Krammer PH. Sensitization of T cells to CD95-mediated apoptosis by HIV-1 Tat and gp120. Nature. 1995; 375:497-500. [PubMed: 7539892]

Wise RA, Bozarth MA. A psychomotor stimulant theory of addiction. Psychol Rev. 1987; 94:469-492. [PubMed: 3317472]

Xiao H, Neuveut C, Tiffany HL, Benkirane M, Rich EA, Murphy PM, Jeang KT. Selective CXCR4 antagonism by Tat: implications for in vivo expansion of coreceptor use by HIV-1. Proc Natl Acad Sci U S A. 2000; 97:11466-11471. [PubMed: 11027346]

Yamashita A, Singh SK, Kawate T, Jin Y, Gouaux E. Crystal structure of a bacterial homologue of Na +/Cl-dependent neurotransmitter transporters. Nature. 2005; 437:215-223. [PubMed: 16041361] 
Yu F, Zhong P, Liu X, Sun D, Gao HQ, Liu QS. Metabotropic glutamate receptor I (mGluR1) antagonism impairs cocaine-induced conditioned place preference via inhibition of protein synthesis. Neuropsychopharmacology. 2013; 38:1308-1321. [PubMed: 23348064]

Yuan Y, Huang X, Midde NM, Quizon PM, Sun WL, Zhu J, Zhan CG. Molecular mechanism of HIV-1 Tat interacting with human dopamine transporter. ACS Chem Neurosci. 2015; 6:658-665. [PubMed: 25695767]

Yuan Y, Huang X, Zhu J, Zhan CG. Computational modeling of human dopamine transporter structures, mechanism and its interaction with HIV-1 transactivator of transcription. Future Med Chem. 2016

Yuan Y, Quizon PM, Sun WL, Yao J, Zhu J, Zhan CG. Role of Histidine 547 of Human Dopamine Transporter in Molecular Interaction with HIV-1 Tat and Dopamine Uptake. Sci Rep. 2016; 6:27314. [PubMed: 27250920]

Zahniser NR, Sorkin A. Rapid regulation of the dopamine transporter: role in stimulant addiction? Neuropharmacology. 2004; 47:80-91. [PubMed: 15464127]

Zauli G, Secchiero P, Rodella L, Gibellini D, Mirandola P, Mazzoni M, Milani D, Dowd DR, Capitani S, Vitale M. HIV-1 Tat-mediated inhibition of the tyrosine hydroxylase gene expression in dopaminergic neuronal cells. J Biol Chem. 2000; 275:4159-4165. [PubMed: 10660577]

Zhao Y, Terry D, Shi L, Weinstein H, Blanchard SC, Javitch JA. Single-molecule dynamics of gating in a neurotransmitter transporter homologue. Nature. 2010; 465:188-193. [PubMed: 20463731]

Zhu J, Ananthan S, Mactutus CF, Booze RM. Recombinant human immunodeficiency virus-1 transactivator of transcription1-86 allosterically modulates dopamine transporter activity. Synapse. 2011; 65:1251-1254. [PubMed: 21538554]

Zhu J, Mactutus CF, Wallace DR, Booze RM. HIV-1 Tat protein-induced rapid and reversible decrease in $[3 \mathrm{H}]$ dopamine uptake: dissociation of $[3 \mathrm{H}]$ dopamine uptake and $[3 \mathrm{H}] 2$ beta-carbomethoxy-3beta-(4-fluorophenyl)tropane (WIN 35,428) binding in rat striatal synaptosomes. J Pharmacol Exp Ther. 2009; 329:1071-1083. [PubMed: 19325033]

Zhu J, Midde NM, Gomez AM, Sun WL, Harrod SB. Intra-ventral tegmental area HIV-1 Tat1-86 attenuates nicotine-mediated locomotor sensitization and alters mesocorticolimbic ERK and CREB signaling in rats. Front Microbiol. 2015; 6:540. [PubMed: 26150803]

Zhu J, Reith ME. Role of the dopamine transporter in the action of psychostimulants, nicotine, and other drugs of abuse. CNS Neurol Disord Drug Targets. 2008; 7:393-409. [PubMed: 19128199]

Zhu J, Yuan Y, Midde NM, Gomez AM, Sun WL, Quizon PM, Zhan CG. HIV-1 transgenic rats display an increase in $[(3) \mathrm{H}]$ dopamine uptake in the prefrontal cortex and striatum. J Neurovirol. 2016; 22:282-292. [PubMed: 26501780] 


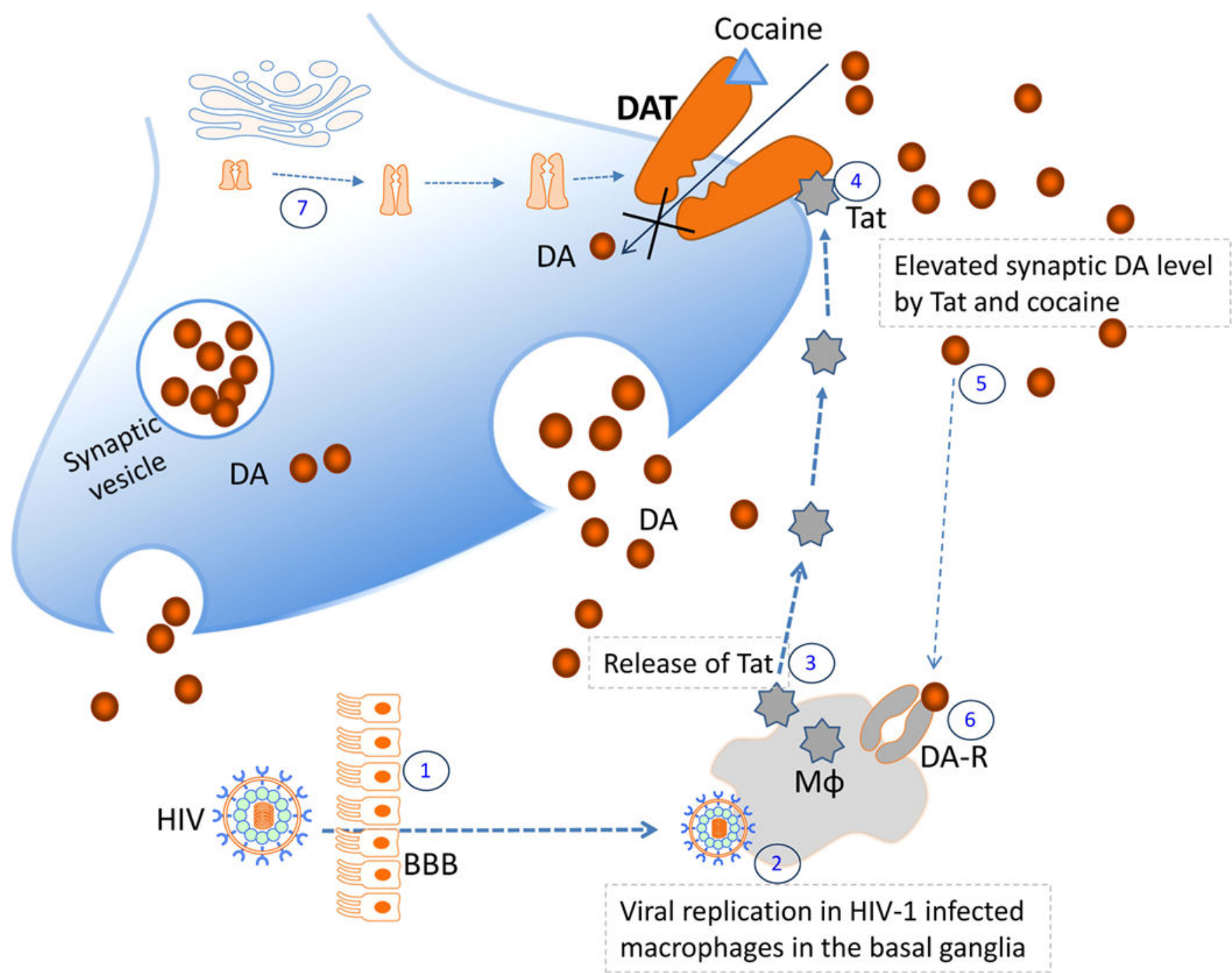

Fig. 1.

Theoretical representation of the role of hDAT in HIV infection-impaired dopaminergic neurotransmission. HIV crosses the blood brain barrier (BBB) in the early of HIV infection (1) and viral replication is happened in macrophages $(\mathrm{M} \phi)$ (2) in the basal ganglia. While virus takes place in macrophages, viral proteins are released (3), which damage DA neurons. Tat and cocaine synergistically elevate DA levels by directly blocking DA transport process (4). The elevated DA (5) further stimulates viral replication and Tat release by activating DA receptors in macrophages (6). In addition, DAT activity can be regulated through trafficking dependent and/or independent mechanisms as well as phosphorylation of subcellular signaling pathways (7), compensating for Tat-induced increase in DA levels and thereby maintaining a constant level of DA at the synaptic cleft. 


\section{Table 1}

Effects of hDAT mutants on basal DA transport and Tat-induced inhibition of DAT function

\begin{tabular}{|c|c|c|c|c|}
\hline & Extracellular loop & $V_{\max }$, DA uptake & $\%$ reduction in the presence of $\mathrm{rTat}_{1-86}(140 \mathrm{nM})$ & Publications \\
\hline WT hDAT & & $100 \%$ & $30 \% \downarrow$ & \multirow{6}{*}{$\begin{array}{l}\text { Midde et al., } 2013 \\
\text { Midde et al., } 2015 \\
\text { Yuan et al., } 2015 \\
\text { Yuan et al., } 2016 \\
\text { Sun et al., } 2017\end{array}$} \\
\hline Y470H & 5 & $86 \%{ }^{*} \downarrow$ & $0 \%$ & \\
\hline Y470F & 5 & $9.0 \% \downarrow$ & $35 \% \downarrow$ & \\
\hline Y470A & 5 & $92 \%{ }^{*} \downarrow$ & $0 \%$ & \\
\hline Y88F & 1 & $6.0 \% \downarrow$ & $0 \%$ & \\
\hline K92M & 1 & $71 \%{ }^{*} \downarrow$ & $0 \%$ & \\
\hline H547A & 6 & $195 \%{ }^{*} \uparrow$ & $0 \%$ & \multirow{4}{*}{$\begin{array}{l}\text { Yuan et al., } 2016 \\
\text { Quizon et al., } 2016 \\
\text { Yuan et al., } 2016\end{array}$} \\
\hline H547P & 6 & $99 \% * \downarrow$ & $0 \%$ & \\
\hline H547R & 6 & $8.0 \% \downarrow$ & $0 \%$ & \\
\hline H547D & 6 & $60 \% * \downarrow$ & $0 \%$ & \\
\hline
\end{tabular}

Pharmacol Ther. Author manuscript; available in PMC 2019 March 01. 